\title{
A risk-based groundwater modeling framework in coastal aquifers: a case study on Long Island, New York, USA
}

\author{
Mohammad Karamouz ${ }^{1} \cdot$ Davood Mahmoodzadeh $^{1,2} \cdot$ Gualbert H. P. Oude Essink $^{2,3}$
}

Received: 10 November 2019 / Accepted: 31 May 2020 / Published online: 21 July 2020

(C) The Author(s) 2020

\begin{abstract}
A methodology is proposed to define indices for quantifying risks under the threat of reducing in groundwater levels, the existence of saltwater intrusion (SWI), and an increasing nitrate contamination load in submarine groundwater discharge (SGD). The proposed methodology considers coastal regions under geological heterogeneity and it is tested on a groundwater system in Nassau County of Long Island, New York (USA). The numerical model is constructed with the SEAWAT code. The parameter uncertainty of this model is evaluated by coupling the Latin hypercube sampling method (as a sampling algorithm) and Monte Carlo simulation to consider the uncertainty in both hydraulic conductivity and recharge rate. The indices are presented in spatial maps that classify areas of risk to potential threats. The results show that two of the water districts have a high risk under conditions of decreasing groundwater level. Salinity occurs in the southern and southwestern parts of the Nassau County aquifer and a considerable area of high risk of SWI is identified. Furthermore, the average SGD rate with the associated fluxes of nitrate is estimated as 81.4 million $\mathrm{m}^{3} /$ year (average 0.8 tons of nitrate through SGD per year), which can adversely affect the quality of life in the local coastal ecosystems. The framework developed in this study could help the water district managers to identify highrisk areas for short-term and long-term planning and is applicable to other coastal settings.
\end{abstract}

Keywords Numerical modeling $\cdot$ Coastal aquifers $\cdot$ Saltwater intrusion $\cdot$ Quantitative indices $\cdot$ USA

\section{Introduction}

Groundwater, as a critical source of freshwater, has a vital role in coastal regions and needs to be assessed against threats. In coastal regions, aquifers are important sources of water supply for domestic, industrial and agricultural consumption. Nowadays, high demand from the coastal groundwater

Mohammad Karamouz

karamouz@ut.ac.ir

Davood Mahmoodzadeh

d.mahmoodzadeh@ut.ac.ir

Gualbert H. P. Oude Essink

gualbert.oudeessink@deltares.nl

1 School of Civil Engineering, University of Tehran, PO Box 14155-6619, Tehran, Iran

2 Department of Physical Geography, Utrecht University, PO Box 3584CS Utrecht, The Netherlands

3 Unit Subsurface and Groundwater Systems, Deltares, PO Box 85467, 3508, AL Utrecht, The Netherlands systems has increased the pressure on these resources (Oude Essink et al. 2010; Ketabchi et al. 2016b; Karamouz et al. 2017, 2020; Klassen and Allen 2017). Saltwater intrusion (SWI) is a main problem in many coastal regions (Post et al. 2018). Also, submarine groundwater discharge (SGD), which is the exchange of groundwater between the land and sea, involves the associated fluxes of nutrients. Further, high water demand causes increase in the groundwater withdrawal and the added stress to coastal aquifers and ecosystems (Small and Nicholls 2003; Moore 2010; Yao et al. 2019; Mahmoodzadeh and Karamouz 2019). In some coastal urban areas such as Nassau County in Long Island, New York (USA), groundwater is the main source of domestic water supply (Suozzi 2005). Protection of this groundwater resource is needed to guarantee a sustainable domestic water source for locals. Therefore, it is important to assess the risk of groundwater pollution in these coastal regions, which could support decision-making in the planning and management of local water resources (Zeng et al. 2016; Lal and Datta 2019; Ketabchi and Ataie-Ashtiani 2015a, b; Moreno et al. 2020).

In coastal regions, the groundwater system is usually recharged by direct infiltration from precipitation and 
surface-water resources. The regional flow of groundwater is commonly toward the ocean, but saltwater intrudes into the aquifers at many locations (Motallebian et al. 2019). Submarine groundwater discharge (SGD) to the ocean includes water flow on continental margins from the seabed to the ocean (Burnett et al. 2003; Moore 2010); moreover, SGD is associated with fluxes of nutrients that can damage coastal ecosystems (Slomp and Van Cappellen 2004; Moore 2010; Zhou et al. 2019). Coastal aquifers are affected by decreasing groundwater levels which can cause subsidence and serious damage to infrastructures (e.g., Minderhoud et al. 2017). Saltwater intrusion threatens the quality of fresh groundwater resources that are used for drinking water. Coastal aquifers are sensitive to natural processes, climate change effects including sea-level rise, and human interventions such as over-pumping (Oude Essink et al. 2010). A comprehensive review of factors that affect SWI and SGD is given by Moore (2010), Werner et al. (2013), and Ketabchi et al. (2016a).

Many researchers are dealing with modeling of the aforementioned threats to quantify their impacts on the groundwater system, while mostly they do not incorporate the risk concepts in the modeling of coastal aquifers. In this concept, risk is determined as the product of the probability of occurrence of an event and the associated consequence (Klassen and Allen 2017). Also, the modeling results are affected by simplifications and assumptions about the groundwater system that are not true for many real-world applications. For instance, considering the same hydraulic conductivity value for each geological layer of a groundwater system is a (very) simple assumption, increasing the uncertainty (Mahmoodzadeh and Karamouz 2017, 2019). Due to the inherent heterogeneity of aquifers, there are several other unavoidable sources of uncertainty such as estimates of hydraulic conductivity, recharge and pumping, in the groundwater models. Therefore, uncertainty analysis should be considered in SWI models (Rajabi and Ketabchi 2017; MostafaeiAvandari and Ketabchi 2020); thus, the analysis of risk for coastal aquifers under present uncertainties, and quantification of potential threats to the groundwater system, is important.

The risk concept has been mostly associated with natural disasters, and a risk-based modeling framework has not typically been applied to the field of coastal hydrogeology. A few studies have considered the risk concept in the coastal groundwater field and applied the concept through different objectives. Recently, Mostafaei-Avandari and Ketabchi (2020) applied a numerical model to determine optimal net recharge rates on each groundwater management zone in a real-case coastal aquifer in Ajabshir, Iran. In that study, the uncertainty is considered only in hydraulic conductivity, and the risks under the threat of decreasing groundwater level and the existence of SWI were not considered. In this context, steps for groundwater pollution assessment were investigated by Massone and Barilari (2019). Their first step introduced the assessment of aquifer vulnerability; in the second step, methodological approaches were developed with regard to risk assessment. Technology and associated approaches were incorporated into the third step. They emphasized that the greatest challenge is to consider the risk of groundwater pollution through an integrated approach.

Eriksson et al. (2018) used a mapping method to estimate the risks of well salinization and the impacts of sealevel rise on the Baltic Sea island of Öland, Sweden. They found that hydrology, geomorphology, and climatology parameters have a significant impact on the risk of SWI. This study highlighted that a salinization risk map, could be useful for decision-makers in the planning of infrastructure. Klassen and Allen (2017) also used a mapping method for quantification of the risk of SWI under natural threats such as sea-level rise and storm surge, and human interventions such as over-pumping, in the Gulf Islands in British Columbia, Canada. They assessed the vulnerability of the aquifer to SWI spatially, by mapping threats considering the aquifer susceptibility. In their study to characterize aquifer susceptibility to SWI, distance from the coast, topographic slope, and groundwater flux were used. Risk assessment maps were useful tools for classifying areas vulnerable to SWI; however, these studies were limited to analytical methods and did not consider the uncertainty analysis of model input parameters.

Holding and Allen $(2015,2016)$ applied a numerical model to assess the risk to water security at low-lying Andros Island, Florida, USA. They presented areas of increasing risk to water security. The risk maps provided useful information to policy makers to identify high-risk areas. In that study, the uncertainty of the model input parameters (variables) was not considered and limited to defining only the risk under water security.

Zeng et al. (2016) used numerical modeling to assess the pollution risk to the groundwater source of western Laizhou Bay, Shandong province, China. Their modelling results demonstrated that the sampling algorithm based on Markov Chain Monte Carlo simulations was efficient and reliable to estimate the model parameters using observed data. Also, their results showed that within the $95 \%$ confidence level, the groundwater system would not be threatened by SWI within the coming 5 years. In that study, the pollution risk to a groundwater source point is assessed under some assumptions which include the simplification of the SWI model and aquifer heterogeneity. Also, the pollution risk is described only by one indicator (i.e. SWI).

Simpson et al. (2014) developed a risk assessment framework for water protection purposes in the Township of Langley, in British Columbia, Canada. They studied risk assessment with respect to groundwater quality associated with different land uses at the ground surface due to manmade interventions. They showed maps of risk to the 
aquifer and demonstrated that the more vulnerable areas have potential chemical and biological threats. Thorn (2011) used the measurement method to evaluate the risk of SWI on a fractured chalk aquifer in Greve, Denmark. They showed how the geochemical analysis could be used to identify areas at risk of SWI and to determine the source of salinity. Their results showed that diffusion from connate formational waters and SWI were the sources of salinity in the study area. However, these studies were limited to analytical methods and did not consider uncertainty analysis of the model input parameters.

A review of studies has shown that there has been a limited number investigation that considered the risk analysis of coastal aquifers. These studies considered the risk analysis under one numerical indicator (i.e. water security or SWI). Of these, in the studies of Holding and Allen (2016) and Nobre et al. (2007), the uncertainty of the model input parameters (variables) was not considered. Also, in the studies of Holding and Allen (2016), Zeng et al. (2016) and Nobre et al. (2007), the heterogeneity of the aquifer and quantitative indices to assess the risk to the groundwater resources under different threats were not considered.

Risk-based groundwater modeling is required to understand and manage groundwater resources with the purpose of predicting long-term and short-term impacts. The contribution of this paper is to consider the risk analysis concerning the decreasing groundwater levels, SWI based on the salinity concentration and the so-called filling ratio, and SGD, which can threaten the quality and quantity of coastal aquifers and ecosystems. SWI based on the filling ratio is a percentage of the occupied volume by saltwater (for example $50 \%$ of salinity concentration of saltwater) to the total volume of the considered aquifer. In this study, a risk-based groundwater modeling framework is developed in which the main feature is the ability to consider the uncertainty in the hydraulic conductivity and recharge rate parameters in a real-world setting. Numerical modelling is performed within a Monte Carlo framework with a Latin hypercube sampling (LHS) algorithm. Four indices are formulated to quantify the risk in the coastal groundwater system, located in Nassau County, Long Island, to obtain susceptible areas to control SWI and decreasing groundwater level. Based on the reviewed studies, such a riskbased groundwater modeling framework has not yet been applied to a real-case coastal groundwater system considering geological heterogeneity.

The rest of the paper is organized as follows: the riskbased groundwater modeling framework is described. Next, the study area, numerical simulations, and indices are described. Then, the risk to the groundwater system under decreasing groundwater level, SWI, and SGD are assessed and discussed. Finally, the main conclusions are drawn from the analysis.

\section{Methodology}

The risk-based groundwater modeling framework for this study is shown in Fig. 1. In this framework, after developing a conceptual model based on the collection of data and information, uncertainty analyses are applied to a real-case study, with a three-dimensional (3D) numerical model, simulating variable-density groundwater flow and coupled salt transport. The simulation component of the uncertainty analyses consists of Monte Carlo simulations (MCSs) followed by a risk analysis based on defined indices. All abbreviations and mathematical terms are defined in the Appendix.

\section{Numerical simulation approach}

The variation of spatial and temporal fresh and salt groundwater is simulated with a $3 \mathrm{D}$ variable-density groundwater model, SEAWAT code (Langevin et al. 2008). Many studies have previously applied this code to simulate variable-density, transient groundwater flow and coupled salt transport, in coastal regions (e.g., Rasmussen et al. 2013; Holding and Allen 2016; Colombani et al. 2016; Huizer et al. 2018).

SEAWAT solves the fluid and the solute equations simultaneously with a cell-centered finite difference approximation to characterize variable-density flow associated with SWI. The fluid equation (Eq. 1) demonstrates the single-phase flow in a porous medium and the solute equation (Eq. 2) describes the solute transport including advection and dispersion mechanisms (Langevin et al. 2008).

$$
\begin{gathered}
\nabla \cdot\left[\rho \frac{\mu_{0}}{\mu} \mathrm{K}_{0}\left(\nabla h_{0}+\frac{\rho-\rho_{0}}{\rho_{0}} \nabla \mathrm{z}\right)\right]=\rho S_{\mathrm{s}, 0} \frac{\partial h_{0}}{\partial t}+\theta \frac{\partial \rho}{\partial C} \frac{\partial C}{\partial t}-\rho_{\mathrm{s}} q_{\mathrm{s}}^{\prime} \\
\left(1+\frac{\rho_{\mathrm{b}} K_{\mathrm{d}}^{k}}{\theta}\right) \frac{\partial\left(\theta C^{k}\right)}{\theta t}=\nabla \cdot\left(\theta \mathrm{D} \cdot \nabla C^{k}\right)-\left(q C^{k}\right)-q_{\mathrm{s}}^{\prime} C_{\mathrm{s}}^{k}
\end{gathered}
$$

where $\rho_{0}$ is the fluid density $\left[\mathrm{M} / \mathrm{L}^{3}\right]$ at the reference concentration and reference temperature, $\mu$ is dynamic viscosity $[\mathrm{M} / \mathrm{L} . \mathrm{T}], \mathrm{K}_{0}$ is the hydraulic conductivity tensor of material saturated with the reference fluid $[\mathrm{L} / \mathrm{T}], h_{0}$ is the head [L] measured in terms of the reference fluid of a specified concentration and temperature, $S_{\mathrm{s}, 0}$ is the specific storage $[1 / \mathrm{L}], \theta$ is porosity [-], $C$ is salt concentration $\left[\mathrm{M} / \mathrm{L}^{3}\right], q_{\mathrm{s}}^{\prime}$ is a source or sink $[1 / \mathrm{T}]$ of fluid with density $\rho_{\mathrm{s}}, \rho_{\mathrm{b}}$ is the bulk density $\left[\mathrm{M} / \mathrm{L}^{3}\right], K_{\mathrm{d}}^{k}$ is the distribution coefficient of species $k\left[\mathrm{~L}^{3} /\right.$ $\mathrm{M}], \mathrm{D}$ is the hydrodynamic dispersion coefficient tensor $\left[\mathrm{L}^{2}\right.$ $/ \mathrm{T}], C^{k}$ is the concentration of species $k\left[\mathrm{M} / \mathrm{L}^{3}\right], q$ is specific discharge $[\mathrm{L} / \mathrm{T}]$, and $C_{\mathrm{s}}^{k}$ is the source or sink concentration $[\mathrm{M} / \mathrm{L}]$ of species $k$.

In this study, the calibration procedure is done using an automated parameter estimation code, PEST (Doherty 2005). The model is calibrated for steady-state groundwater level (head) and solute (chloride concentration). Due to limited observation information on chloride concentration, 


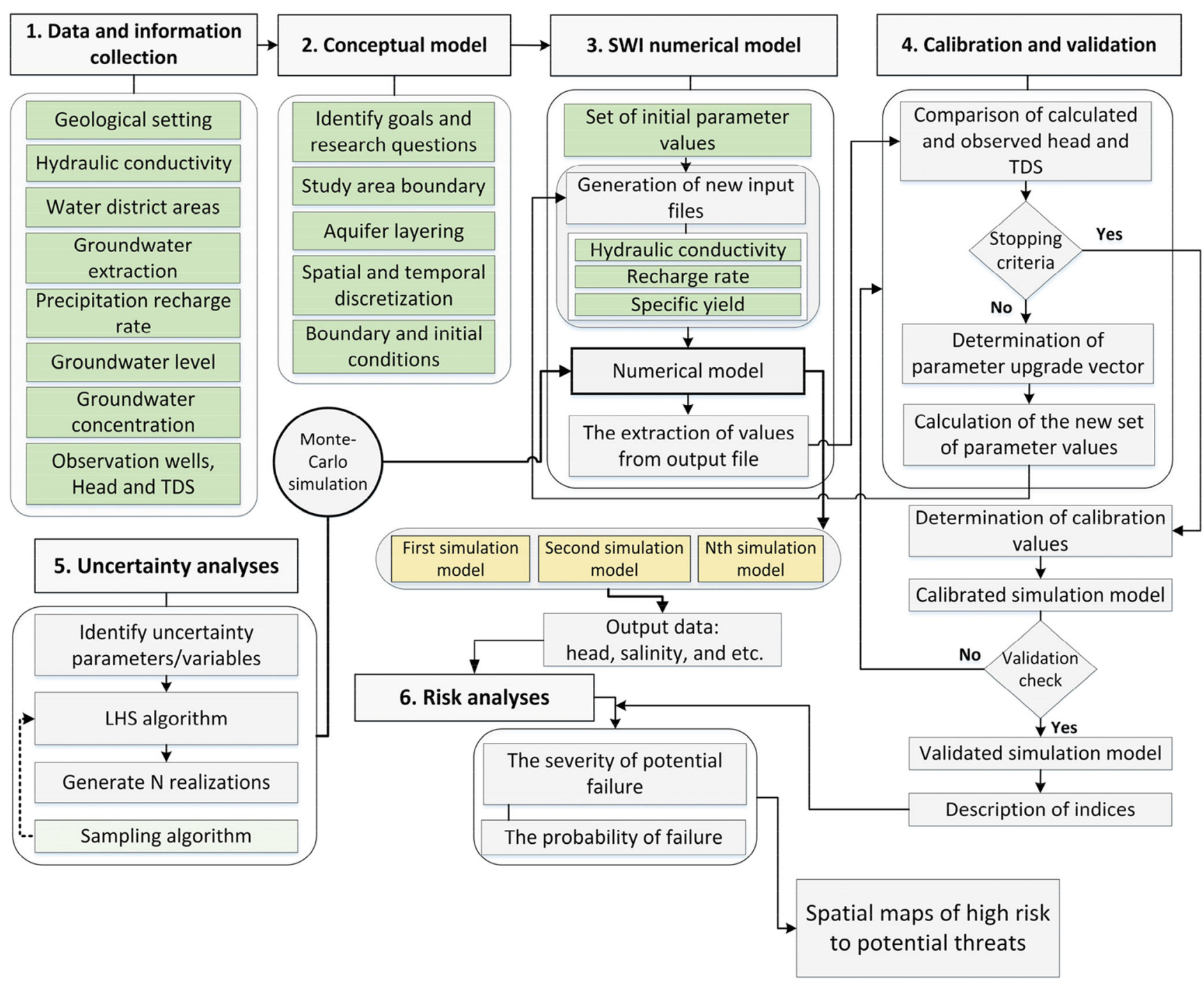

Fig. 1 The risk-based groundwater modeling framework

calibration and validation of the transient model are performed for groundwater level. A primary adjustment of model input parameters and variables, i.e. the hydraulic conductivity and recharge rate, is made to reduce the difference between the observed and the simulated groundwater level.

\section{Uncertainty and risk analysis approaches}

Monte Carlo simulations as a sampling-based method is most widely used for uncertainty analysis, with a wide range of applications in different fields such as SWI modeling (see Rajabi and Ketabchi 2017; Mahmoodzadeh and Karamouz 2019). In this approach, mathematical problems are solved by the simulation of random variables. MCSs have been employed to analyze the propagation of uncertainty from input variables/parameters such as hydraulic conductivity, porosity, recharge and pumping rate, to output quantities such as simulated head and concentration. The uncertainty of input is considered through the definition of a probability density function.

The limitation of the Monte Carlo method is the efficacy of the result, which depends on a large number of samples to get an acceptable representation of the distribution function. In overcoming this problem and to reduce the required number of MCSs, sampling selection methods such as LHS algorithm are used (see previous studies like Lassila et al. 1999; Baalousha 2003; Dimov 2008; Rajabi and Ataie-Ashtiani 2014). LHS is known as a stratified Monte Carlo sampling method. In this method, the domain of each random variable/ parameter is divided into the interval with the same probability in all the intervals. From each interval, a value is randomly selected regarding the probability density in the interval. In this study, the hydraulic conductivity and recharge rate are considered to be uncertain input parameters. Also, the LHS algorithm is employed to generate the samples. 
Based on the results of MCSs, the probability of failure is evaluated. For estimating the probability of a failure event, a realization for a random variable based on the probability distribution function is generated. Then, the performance function based on the simulation model for each random variable $x$ is assessed. The following function can be identified by (Press et al. 1992):

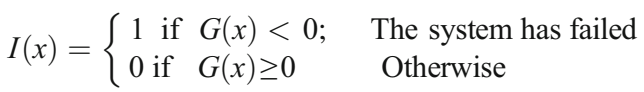

where $I(x)$ is the output of the simulation model for each random variable $x$, and $G(x)$ is the performance function. The probability of failure is estimated as follows:

$P_{\mathrm{f}}=\int_{G(x)<0} f_{x}(x) d x$

where $P_{\mathrm{f}}$ is the probability of failure and $f_{x}(x)$ is the probability density function of the random variables $x$. Based on Eqs. (3) and (4), the probability of failure is calculated for each realization as follows:

$E\left[P_{\mathrm{f}}\right]=\frac{1}{N_{\mathrm{MCS}}} \int_{n=1}^{N_{\mathrm{MCS}}} P_{n} ; P_{\mathrm{f}}=\frac{N_{\mathrm{f}}}{N_{\mathrm{MCS}}}$

where $N_{\mathrm{f}}$ is the number of failures and $N_{\mathrm{MCS}}$ is the total number of MCSs.

The risk is determined by the product of two components (Eq. 6) which are the probability of an event and the proposed potential consequences/loss (Klassen and Allen 2017). The two components of risk, namely the probability of a failure event and the severity of a failure event, are required to be quantified for all indices.

$\operatorname{Risk}\left(R_{m}\right)=C_{m} \times P\left(C_{m}\right)$

where $C_{m}$ is the indicating characteristic of potential loss and $P\left(C_{m}\right)$ is the probability of the potential loss. Also, $m$ denotes a specific event. The probability of a failure event is the exceedance of an indicator defined to monitor the groundwater resources, based on the MCSs from a certain threshold. The threshold represents the allowable level of risk and the severity of a failure event is the difference between the simulated and the allowable conditions of the index. The allowable level of risk and the severity of a failure event are described in the following subsections for each index.

\section{Description of indices}

Quantitative indices are used to assess the risk of the current state of groundwater resources considering different threats. The four indices are (1) the depletion of groundwater level ( $\left.H_{\mathrm{GWL}}\right)$; (2) salinity concentration $\left(C_{\mathrm{swi}}\right)$ of the groundwater system; (3) volume of SWI based on the filling ratio $\left(\mathrm{FR}_{\text {swiv }}\right)$; and (4) the average contamination load discharged through SGD $\left(\mathrm{CL}_{\mathrm{SGD}}\right)$. Although the second and third indices represent the SWI, different practical concepts are introduced for each location and each layer of the study area. These indices can provide a basis to develop sustainable management decisions.

\section{Decrease of groundwater level}

In the first index, the objective is defined to assess the risk of the decrease of groundwater level. The probability of exceedance of the groundwater level $[-]$, denoted by $P\left(H_{\mathrm{GWL}}^{x, y}\right)$, is defined from a certain threshold as:

$$
\begin{gathered}
P\left(H_{\mathrm{GWL}}^{x, y}\right)=\frac{\int_{T} N_{M C S}^{H_{t}^{x, y}} \leq H_{t}^{\text {allow }}}{T \times N_{\mathrm{MCS}}} \\
H_{t}^{\text {allow }}=H_{\mathrm{min}, t, k}^{\mathrm{x}, \mathrm{y}}=\min \left(H_{t, k}^{x, y}\right)
\end{gathered}
$$

$L\left(H_{\mathrm{GWL}}^{x, y}\right)=\frac{\int_{T} \int_{K} \Delta H_{t, k}}{T \times N_{\mathrm{MCS}}}$

$\Delta H_{t, k}=\left\{\begin{array}{l}H_{t}^{\text {allow }}-H_{t, k}^{x, y} \text { if } H_{t, k}^{x, y} \leq H_{t}^{\text {allow }} \\ 0 \text { if } H_{t, k}^{x, y}>H_{t}^{\text {allow }}\end{array}\right.$

where $N_{\text {MCS }}^{H_{t}^{x, y} \leq H_{t}^{\text {allow }}}$ is the total number of MCSs resulting [-] in the decrease of groundwater level below $H_{t}^{\text {allow }}$ in each location of the groundwater system (i.e. $x, y$ ), $N_{\mathrm{MCS}}$ is the total number of MCSs, $T$ is the total number of assumed stress periods, $H_{t}^{\text {allow }}$ represents the allowable decrease of the groundwater level [L] and is assumed to be $(1 \pm \alpha) \times H_{\text {min, }, t, k}^{x, y}$ where $(1 \pm \alpha)$ is the confidence level for the interval, $t$ is the stress period [T], and $H_{\text {min.t, }, k}^{x, y}$ is the minimum groundwater level [L] among all number of realizations under the zeroextraction scenario (it comprises lower bounds that bracket a future unknown value with a certain confidence level). In this study, the zero-extraction scenario (as the natural condition without human-induced groundwater extraction) is defined as the condition whereby groundwater withdrawal using pumping wells not happen throughout the simulation period. $L\left(H_{\mathrm{GWL}}^{x, y}\right)$ is the severity of the failure event [-] and is defined as the difference (denoted by $\Delta H_{t, k}$ ) between the decrease of $H_{t}^{\text {allow }}$ and the decrease of groundwater level at each location in the aquifer in the $t$ th stress period, for the $k$ th realization. The counter $K$ is the total number of realizations (equal to $150)$.

\section{Salinity concentration}

Salinity concentration in each location of the groundwater system is calculated with a certain threshold (denoted by $C_{\mathrm{Tr}}$ ) and defined as SWI: 


$$
\begin{aligned}
& C_{\mathrm{swi}, t}^{x, y z}=\left\{\begin{array}{cl}
C_{t}^{x, y, z} & \text { if } C_{C^{x}, y, z}^{x, y} \geq C_{\mathrm{Tr}} \\
0 & \text { if } C_{t}^{x, y, z}<C_{\mathrm{Tr}}
\end{array}\right. \\
& C_{\mathrm{Tr}}=0.002 C_{\mathrm{SW}}, 0.05 C_{\mathrm{SW}}, 0.5 C_{\mathrm{SW}}, \text { and } 0.95 C_{\mathrm{SW}}
\end{aligned}
$$

where $C_{\mathrm{swi}, t}^{x, y, z}$ is the salinity concentration $\left[\mathrm{M} / \mathrm{L}^{3}\right]$ at each location and depth in the groundwater system, i.e. $x, y$, and $z$, and $C_{\operatorname{Tr}}$ is a threshold for the commonly used $0.2,5,50$, and $95 \%$ of salinity concentration of saltwater $\left(C_{\mathrm{sw}}\right)\left[\mathrm{M} / \mathrm{L}^{3}\right]($ see Mahmoodzadeh and Karamouz 2019). The salinity concentration equal to $0.2 \%$ saltwater is defined as potable fresh groundwater (NYSDOH 2003).

The probability of exceedance of salinity concentrations at each location in the aquifer is defined from a certain threshold as:

$$
\begin{aligned}
& P\left(C_{\mathrm{swi}}^{x, y, z}\right)=\frac{\int_{T} N_{\mathrm{MCS}}^{C_{\mathrm{swi}, t}^{x, y} \geq C_{\mathrm{swi}, t}^{\text {allow }}}}{T \times N_{\mathrm{MCS}}} \\
& C_{\mathrm{swi}, t}^{\text {allow }}=C_{\mathrm{max}, \mathrm{swi}, t}^{x, y, z}=\max \left(C_{\mathrm{swi}, k, t}^{x, y, z}\right) \\
& L\left(C_{\mathrm{swi}}^{x, y, z}\right)=\frac{\int_{T} \int_{K} \Delta C_{t, k}}{T \times N_{\mathrm{MCS}}} \\
& \Delta C_{t, k}=\left\{\begin{array}{ccc}
C_{\mathrm{swi}}^{x, y, z}-C_{\mathrm{swi}, t}^{\text {allow }} & \text { if } & C_{\mathrm{swi}, t, k}, y, z \geq C_{\mathrm{swi}, t}^{\text {allow }} \\
0 & \text { if } & C_{\mathrm{swi}, t, k}^{x, y}<C_{\mathrm{swi}, t}^{\text {allow }}
\end{array}\right.
\end{aligned}
$$

where $P\left(C_{\text {swi }}^{x, y, z}\right)$ is the probability of exceeding the SWI [-] at each location in the aquifer, i.e. $x, y, z$, from a certain threshold (denoted by $C_{\mathrm{swi}, t}^{\mathrm{allow}}$ ), $N_{\mathrm{MCS}}^{C_{\mathrm{sw}, t}^{\mathrm{x}, z} \geq C_{\mathrm{swi}, t}^{\mathrm{allow}}}$ is the number of MCSs resulting [-] in salinity concentrations of the SWI above the threshold, $C_{\text {swi.t }}^{\text {allow }}$ represents the allowable level of risk for salinity concentrations $\left[\mathrm{M} / \mathrm{L}^{3}\right]$ of SWI and assumed to be $(1 \pm \alpha) \times C_{\text {max,swi, } t}^{x, y, z}$ where $C_{\text {max,swi, } t}^{x, y, z}$ as the maximum of salinity concentration $\left[\mathrm{M} / \mathrm{L}^{3}\right]$ among all realizations under zeroextraction scenarios, and $L\left(C_{\text {swi }}^{x, y, z}\right)$ is the magnitude of the failure event [-] which is defined as the difference (denoted by $\left.\Delta C_{t, k}\right)$ between the salinity concentrations $\left(C_{\mathrm{swi}, t, k}^{x, y, z}\right)$ and the $C_{\mathrm{swi}, t}^{\mathrm{allow}}$ (in the $k$ th realization and the $t$ th stress period).

\section{Filling ratio}

The volume of SWI based on the filling ratio (FR) index (Van Camp et al. 2010), defined as the ratio of the occupied volume by saltwater to total volume of the considered aquifer layer, is calculated according to Eq. (12).

$$
\begin{aligned}
& \mathrm{FR}_{\mathrm{swiv}}^{i}=\frac{\int_{T} \int_{J} V_{j, t}^{i}}{T \times \theta \times \int_{J} V_{j}^{i}} \forall i, \forall j, \forall t \\
& V_{j, t}^{i}=\left\{\begin{array}{l}
V_{j, t}^{i} \text { if } C_{j, t}^{i} \\
0 \text { if } C_{j, t}^{i}<C_{\mathrm{Tr}} C_{\mathrm{Tr}}=0.002 C_{\mathrm{sw}}, 0.05 C_{\mathrm{sw}}, 0.5 C_{\mathrm{sw}}, \text { and } 0.95 C_{\mathrm{sw}}
\end{array}\right.
\end{aligned}
$$

where $\mathrm{FR}_{\text {swiv }}^{i}$ is the ratio of the occupied volume by saltwater in the $i$ th model layer [-], $V_{j, t}^{i}$ is the volume of SWI $\left[\mathrm{L}^{3}\right]$ in the $i$ th model layer, in the $j$ th model cell, and in the $t$ th stress period, $V_{j}^{i}$ is volume of the model cell $\left[\mathrm{L}^{3}\right], \theta$ is porosity $[-]$, $C_{j, t}^{i}$ is the salinity concentration $\left[\mathrm{M} / \mathrm{L}^{3}\right]$, and $C_{\operatorname{Tr}}$ is a certain threshold for the salinity concentration $\left[\mathrm{M} / \mathrm{L}^{3}\right]$. The threshold is defined by the exceedance of the salinity concentration in each model cell from specified thresholds, i.e. 0.02, 5, 50, and $95 \%$ of salinity concentration of saltwater. The counter $i$ is the number of model layers (equal to 14), and $j$ is the number of model cells in each model layer. To assess the risk of SWI, based on Eqs. (13) and (14):

$$
\begin{aligned}
& P\left(\mathrm{FR}_{\text {swiv }}^{i}\right)=\frac{N_{\mathrm{MCS}}^{F R_{\text {swiv }}^{i} \geq F R_{\text {swiv }}^{\text {allow }}}}{N_{\mathrm{MCS}}} \\
& \mathrm{FR}_{\mathrm{swiv}}^{\text {allow }}=\mathrm{FR}_{\text {max }, \text { swiv }}^{i, z}=\max \left(\mathrm{FR}_{\mathrm{swiv}, k}^{i, z}\right)
\end{aligned}
$$

$$
\begin{aligned}
L\left(\mathrm{FR}_{\mathrm{swiv}}^{i}\right) & =\frac{\int_{K} \Delta \mathrm{FR}_{\mathrm{swiv}, k}}{N_{\mathrm{MCS}}} \\
\Delta \mathrm{FR}_{\mathrm{swiv}, k} & =\left\{\begin{array}{ccc}
\mathrm{FR}_{\mathrm{swiv}, k}^{i}-\mathrm{FR}_{\mathrm{swiv}}^{\text {allow }} & \text { if } & \mathrm{FR}_{\mathrm{swiv}, k}^{i} \geq \mathrm{FR}_{\mathrm{swiv}}^{\text {allow }} \\
0 & \text { if } & \mathrm{FR}_{\mathrm{swiv}, k}^{i}<\mathrm{FR}_{\mathrm{swiv}}^{\text {allow }}
\end{array}\right.
\end{aligned}
$$

where $P\left(\mathrm{FR}_{\text {swiv }}^{i}\right)$ is the probability of exceeding the ratio of the occupied volume by saltwater [-] in the $i$ th model layer from a certain threshold (denoted by $\mathrm{FR}_{\text {swiv }}^{\text {allow }}$ ), and $N_{\mathrm{MCS}}^{\mathrm{FR}_{\text {swiv }}^{i}} \geq \mathrm{FR}_{\text {swiv }}^{\text {allow }}$ is the number of MCSs resulting [-] in the filling ratio of SWI above $\mathrm{FR}_{\text {swiv }}^{\text {allow }}$. The threshold represents the allowable level of risk for the filling ratio of SWI and it is assumed to be $(1 \pm \alpha) \times \mathrm{FR}_{\text {max,swiv }}^{i, z} \cdot \mathrm{FR}_{\text {max,swiv }}^{i, z}$ is the maximum of filling ratio $[-]$ among all realizations under the zero-extraction scenario, and $L\left(\mathrm{FR}_{\text {swiv }}^{i}\right)$ is the severity of the failure event [-] which is defined as the difference (denoted by $\Delta \mathrm{FR}_{k}$ ) between the ratio of the occupied volume by saltwater $\left(\mathrm{FR}_{\mathrm{swiv}, k}^{i}\right)$ and the $\mathrm{FR}_{\text {swiv }}^{\text {allow }}$. 


\section{Submarine groundwater discharge}

The average concentration of contamination (nitrate here) load discharged through SGD $[\mathrm{M} / \mathrm{T}]$ (denoted by $\mathrm{CL}_{\mathrm{SGD}}$ ), as discharging flow out of the aquifers to the sea, is calculated according to Eq. (15).

$\mathrm{CL}_{\mathrm{SGD}}=\frac{\int_{T} \bar{C} \times \mathrm{SGD}_{t}}{T}$

where $\bar{C}$ is the average concentration $\left[\mathrm{M} / \mathrm{L}^{3}\right]$ (the average nitrate concentration in the study area), and $\mathrm{SGD}_{t}$ is discharging flow out of the aquifers to the sea in each stress period $\left[\mathrm{L}^{3} / \mathrm{T}\right]$. The probability of exceedance of the average contamination load that discharges through SGD to the sea from a certain threshold (denoted by $\mathrm{CL}_{\mathrm{SGD}}^{\text {allow }}$ ) is estimated as:

$$
\begin{aligned}
& P\left(\mathrm{CL}_{\mathrm{SGD}}\right)=\frac{N_{\mathrm{MCS}}^{\mathrm{CL}_{\mathrm{SGC}} \geq \mathrm{CL}_{\mathrm{SGD}}^{\text {allow }}}}{N_{\mathrm{MCS}}} \\
& \mathrm{CL}_{\mathrm{SGD}}^{\text {allow }}=\mathrm{CL}_{\text {max }, \mathrm{SGD}, \mathrm{z}}^{\text {allow }}=\max \left(\mathrm{CL}_{\mathrm{SGD}, \mathrm{z}}^{\text {allow }}\right)
\end{aligned}
$$

$$
\begin{aligned}
& L\left(\mathrm{CL}_{\mathrm{SGD}}\right)=\frac{\int_{K} \Delta \mathrm{CL}_{\mathrm{k}}}{N_{\mathrm{MCS}}} \\
& \Delta \mathrm{CL}_{k}=\left\{\begin{array}{cll}
\mathrm{CL}_{\mathrm{SGD}, k}-\mathrm{CL}_{\mathrm{SGD}}^{\text {allow }} & \text { if } & \mathrm{CL}_{\mathrm{SGD}, k} \geq \mathrm{CL}_{\mathrm{SGD}}^{\text {allow }} \\
0 & \text { if } & \mathrm{CL}_{\mathrm{SGD}, k}<\mathrm{CL}_{\mathrm{SGD}}^{\text {allow }}
\end{array}\right.
\end{aligned}
$$

where $N_{\mathrm{MCS}}^{\mathrm{CL}_{\mathrm{SGD}} \geq \mathrm{CL}_{\mathrm{SGD}}^{\text {allow }}}$ is the number of MCSs resulting [-] in the average contamination load higher than $\mathrm{CL}_{\mathrm{SGD}}^{\text {allow }}$ of the aquifer. The threshold represents the allowable level of risk for the contamination load and is assumed to be $(1 \pm \alpha) \times \mathrm{CL}_{\max , \mathrm{SGD}, z}^{\text {allow }}$. $\mathrm{CL}_{\max , \mathrm{SGD}, z}^{\text {allow }}$ is a maximum contamination load $[\mathrm{M} / \mathrm{T}]$ among all realizations under the zero-extraction scenario. $L\left(\mathrm{CL}_{\mathrm{SGD}}\right)$ is defined as the difference (denoted by $\Delta \mathrm{CL}_{\mathrm{k}}$ ) between the average contamination of the aquifer in the $k$ th realization and the $\mathrm{CL}_{\mathrm{SGD}}^{\text {allow }}$.

\section{Application}

The proposed methodology is applied to a part of Nassau County in the state of New York, USA.

\section{Study area}

The study area has an area of $204 \mathrm{~km}^{2}$ and is located in Nassau County, on western Long Island between $40^{\circ} 34^{\prime}$ to $40^{\circ} 55^{\prime} \mathrm{N}$ latitude and $73^{\circ} 44^{\prime}$ to $73^{\circ} 34^{\prime} \mathrm{E}$ longitude (Fig. 2a). This area is dependent on groundwater meet residential, commercial, and industrial demands. The portion attributed to commercial and industrial demand is minimal (about 10\%). The groundwater is critically important to the health and security of all residents (Suozzi 2005). In this area, the groundwater flows naturally towards the Atlantic Ocean and Long Island Sound on the south shore and on the north shore respectively, where it eventually encounters saltwater. Groundwater withdrawal and the decrease in groundwater levels has caused the quality of this groundwater to be threatened by SWI (Gulotta 1998; Suozzi 2005). It is important to monitor the groundwater system and to implement appropriate

(a)
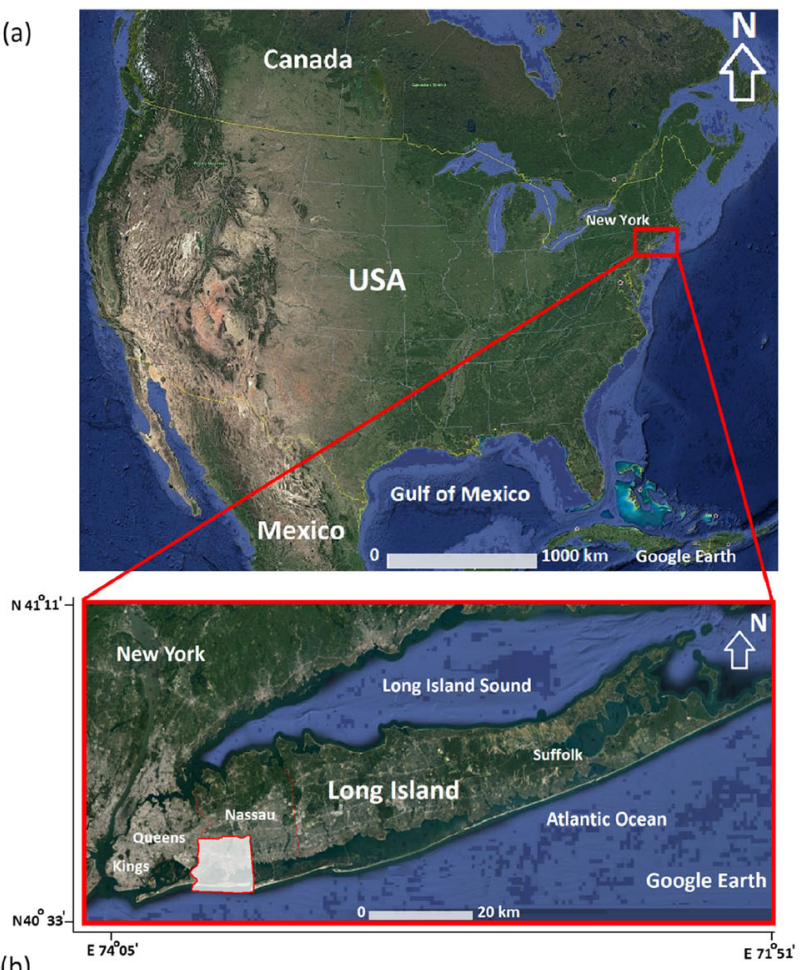

(b)

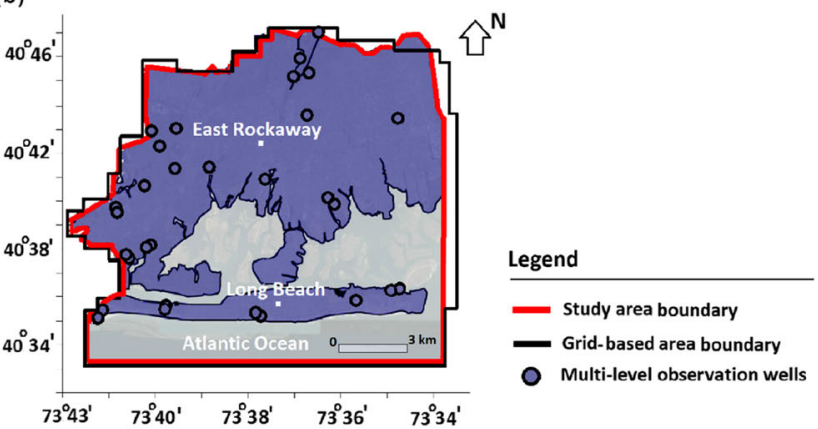

Fig. 2 a map of the study area in Nassau County, New York, USA, and b the locations of the observation wells (map source: New York State, Earthstar Geographics, Esri, Garmin) 
actions to address the SWI problem; therefore, the riskbased numerical modeling approach has been set up to understand the behavior of groundwater resources that face SWI and decreasing groundwater levels. Figure 2 shows a map of the study area and the locations of the multi-level observation wells (USGS 2019a, b, c) in Nassau County.

In the study area, 36 observation wells are used to monitor groundwater levels and the extent of SWI in the three main aquifers. The main characteristics of the study area are summarized in Table 1. As shown in this table, the area's climate is classified as humid subtropical. The long-term average (about 45 years) precipitation in Nassau County is approximately $1,117.6 \mathrm{~mm} /$ year. Accounting for groundwater extraction for consumption by residential, commercial, and industrial users, the net recharge to the groundwater system is estimated to be $29-57 \%$ of the average annual precipitation (Peterson 1987; Suozzi 2005).

\section{Geological setting}

The geological units that contain fresh groundwater in Nassau County consist of three major aquifers: the Upper glacial, the Magothy, and the Lloyd. The geological layers of the study area are shown in Fig. 3. The Lloyd aquifer is a wedge of unconsolidated gravel, sand, silt and clay deposits, and it is underlain by consolidated rock. Above the Lloyd aquifer, there is a major relatively impermeable clay layer (the Raritan formation). This layer is overlain by the Magothy formation. Most of the Magothy formation consists of clay and silty fine to medium sand, some gravel, and thin clay layers. Overlying the Magothy formation, there are several units which include the Jameco gravel, the Gardiners clay, and the upper Pleistocene deposits (upper glacial formation). The Gardiners clay and Jameco in the upper part of the Magothy formation in some places cause a confining layer (Perlmutter and Geraghty 1963; Lusczynski and Swarzenski 1966). The type of material for each geological layer varies considerably from location to location and also varies considerably with depth. Generally, the Magothy and Lloyd aquifers are thickest below the south shore.

All geological layers and their thickness are schematized in Fig. 3. Smaller aquifers such as Jameco and clay layers such as Gardiners clay, increase the complexity of the groundwater system and affect aquifer behavior in parts of Nassau County. The geologic setting of Long Island and Nassau County is described in previous reports such as Perlmutter and Geraghty (1963); Lusczynski and Swarzenski (1966); Smolensky et al. 1989 and Suozzi (2005).

\section{Groundwater recharge and withdrawal}

In the study area, the groundwater system is recharged by direct infiltration from precipitation as a natural source of freshwater. It is also recharged by return flows through onsite septic systems, leaking watersupply or sewer lines, and by infiltration into (mainly Magothy) aquifers by lateral flows, in the northern sections (Buxton and Smolensky 1999). The outflow from
Table 1 Main characteristics of the study area

\begin{tabular}{ll}
\hline Characteristic & Description $^{\mathrm{a}}$ \\
\hline Location & $\begin{array}{l}\text { Long Island, New York, USA } \\
40^{\circ} 34^{\prime}-40^{\circ} 55^{\prime} \mathrm{N}\end{array}$ \\
& $73^{\circ} 44^{\prime}-73^{\circ} 34^{\prime} \mathrm{E}$ \\
Population (million, in 2015) & $1.36^{\mathrm{b}}$ \\
Study area (km ${ }^{2}$ ) & $\sim 204$ \\
Minimum elevation above NAVD $88(\mathrm{~m})$ & $0^{\mathrm{c}}$ \\
Maximum elevation above NAVD 88 (m) & $\sim 12.2^{\mathrm{c}}$ \\
Climate & Humid subtropical $^{\mathrm{b}}$ \\
Average annual precipitation (mm/year) & $1,117.6^{\mathrm{b}}$ \\
Average annual groundwater withdrawal (million m ${ }^{3} /$ day) & $60.85^{\mathrm{d}}$ \\
Rate of recharge to the groundwater system (\%) & $29-57 \%$ of precipitation $^{\mathrm{b}}$ \\
Average depth to water level (m) & $\sim 6$ \\
Average saturated thickness (m) & 244 \\
Number of observation wells & 36 \\
\hline a Based on Suozzi (2005), USGS (2019a), Peterson (1987), and Gulotta (1998) & \\
${ }^{\mathrm{b}}$ Nassau County & \\
${ }^{\mathrm{c}}$ The North American Vertical Datum, which is approximately equal to mean sea level (MSL) \\
${ }^{\mathrm{d}}$ Average annual based on years 1990-2012
\end{tabular}




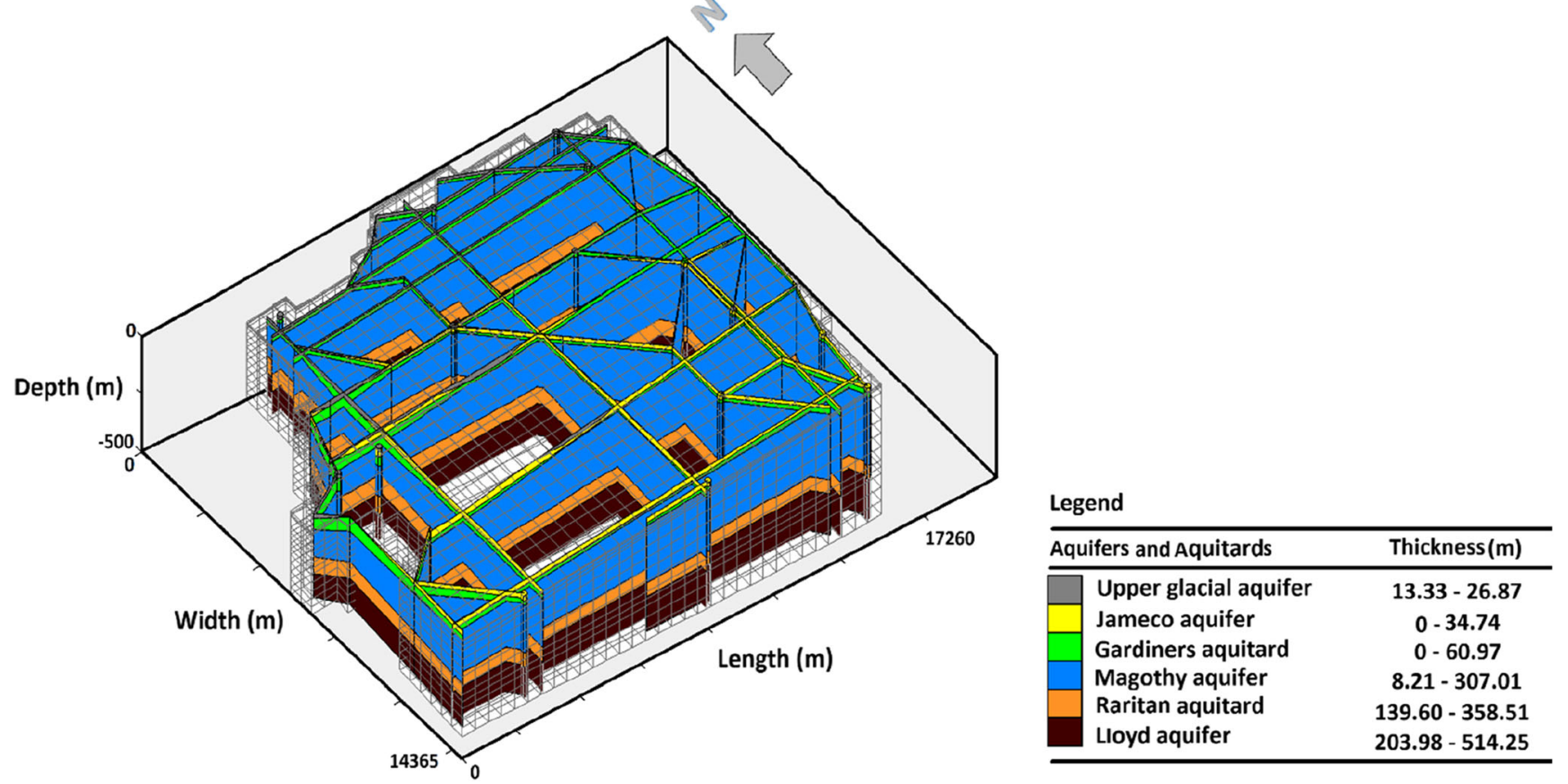

Fig. 3 Geological setting including the geological layers, the aquifers and the aquitards as well as the average thickness values

the groundwater system includes withdrawals from the aquifers through pumping wells, as well as submarine groundwater discharge. About $29-57 \%$ of the precipitation (depending on the land-cover type and degree of urban development), is recharged to the groundwater system, and the remaining water flows as surface runoff to streams or is lost through evapotranspiration (Peterson 1987; Cohen et al. 1968). The groundwater consumption is about $97 \%$ compared to surface-water supply and bottled water, and the water is delivered by the public water suppliers. As shown in Fig. 4, there are nine water districts in this area. About $20 \%$ (in the sewered areas) of the water pumped for public water supply is estimated to return to the groundwater system (Buxton and Smolensky 1999).

In each water districts, recharge by the infiltration of precipitation is estimated as a percentage of mean annual precipitation.
Return flows are estimated and introduced into the simulation model with separate values for each water district. It is assumed that approximately $20-30 \%$ of the consumed domestic water returns to the aquifers (Suozzi 2005; Buxton and Smolensky 1999). Due to the high uncertainty associated with determining inputs and outputs, the estimates of recharge from precipitation and return flows are subjected to calibration in the simulation procedure. Fig. 5 shows the fluctuation of the average groundwater withdrawal for each month the long period of study. The average temperatures in the months of June, July and August are high (about $21-22{ }^{\circ} \mathrm{C}$ ), and these conditions cause a considerably larger water demand than the base demand in the months of January, February, March, November, and December. The highest and the lowest groundwater withdrawals are about 193.5 and 350.4 million $\mathrm{m}^{3} / \mathrm{year}$ in the July and December months, respectively.

Fig. 4 Water district areas in the study area (map source: New York State, Earthstar Geographics, Esri, Garmin)

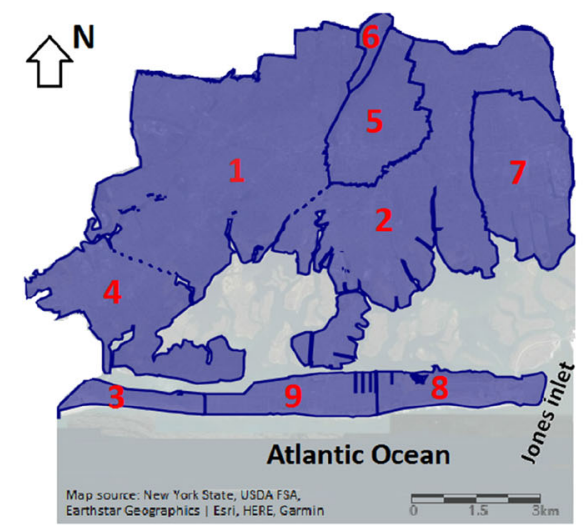




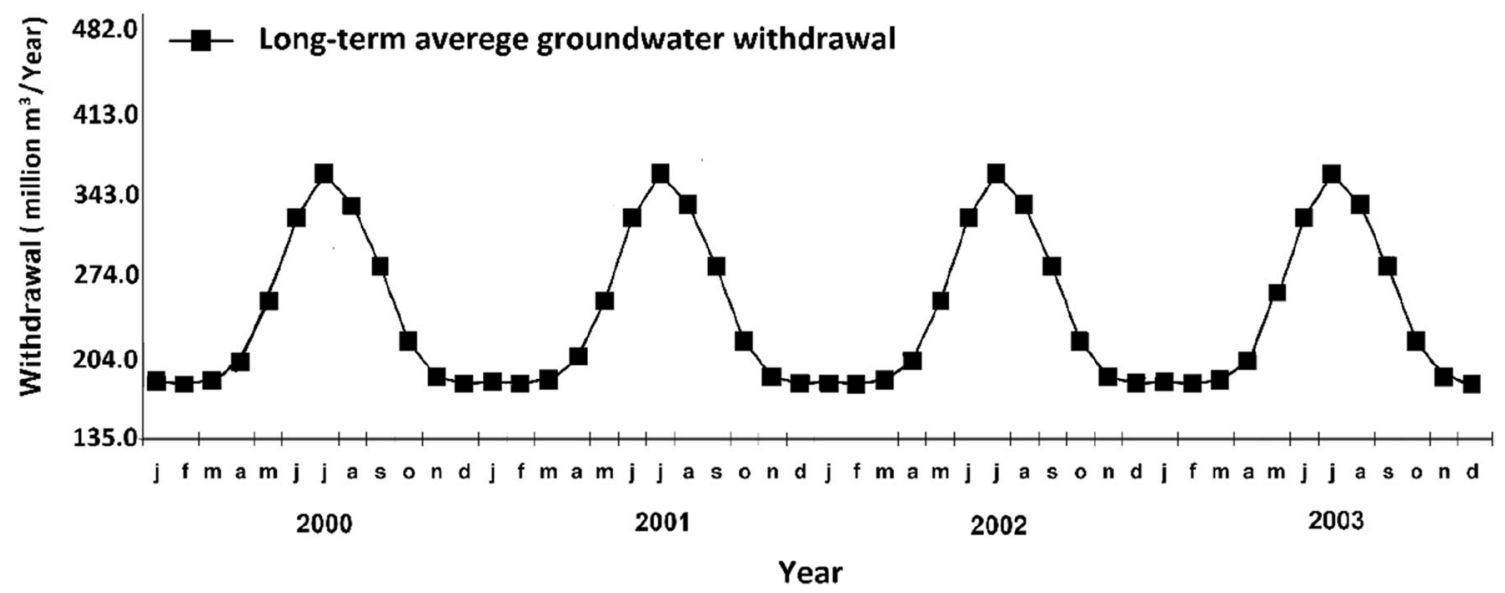

Fig. 5 Long-term average groundwater withdrawal (Adopted from Suozzi 2005)

Table 2 shows the average annual groundwater withdrawal from the different aquifers for the years 19902012. As shown, the highest and lowest groundwater withdrawals are in water districts Nos. 1-4 and water district Nos. 6, respectively.

\section{Saltwater intrusion}

The historical chloride data for water sampled from SWImonitoring wells near the shoreline show increasing chloride concentrations. Analysis of the data shows that SWI occurs at the northern shore and the southwestern part of Nassau County. In southwest Nassau, SWI occurs in both Magothy and Lloyd aquifers due to mainly groundwater withdrawal (Suozzi 2005).

SWI is quantified by means of total dissolved solids (TDS) concentration; however, in the SWI-monitoring wells, chloride concentration is measured. The measured chloride concentrations are converted to salinity (TDS) based on the relation between chloride and TDS, as reduced from data in the sea offshore Long Island, i.e. $1 \mathrm{~g} / \mathrm{L} \mathrm{Cl}$ is similar to $1.84 \mathrm{~g} / \mathrm{L}$ TDS. The chloride concentration in pure saltwater is approximately $19 \mathrm{~g} / \mathrm{L} \mathrm{Cl}(35 \mathrm{~g} / \mathrm{L}$ TDS) (Suozzi 2005; Misut and Voss 2004).
Based on Stumm et al. (2002) and Suozzi (2005) studies, fresh groundwater for Long Island can be defined as water with a concentration of less than $0.074 \mathrm{~g} / \mathrm{L}$ TDS; brackish groundwater has a concentration of $0.074-0.46 \mathrm{~g} / \mathrm{L} \mathrm{TDS}$; and (saline) saltwater has a concentration greater than $0.46 \mathrm{~g} / \mathrm{L}$ TDS. The historical data from the SWI-monitoring wells in the shore aquifers of the southern part of the study area show that the average TDS concentrations is $0.11 \mathrm{~g} / \mathrm{L}$ TDS in the Upper Glacial, $5.70 \mathrm{~g} / \mathrm{L}$ TDS in the Magothy, and $0.031 \mathrm{~g} / \mathrm{L}$ TDS in the Lloyd aquifers.

\section{Numerical simulations}

To simulate variable-density groundwater flow and coupled salt transport, the finite difference SEAWAT code (Langevin et al. 2008 ) is used. In this study, the impacts of coastal flooding due to storm surge, sea-level rise and variation of temperature and precipitation, are not considered. Also, in line with all previous studies (e.g. Narayan et al. 2007; Yang et al. 2013 and Xiao et al. 2019), the impacts of tidal fluctuations on the interface of saltwater and freshwater are small and are neglected. A brief description of the numerical modeling processes is presented in the
Table 2 Average annual groundwater withdrawal in study area

\begin{tabular}{lll}
\hline Water district area (No.) & Aquifer & Average annual withdrawal (million $\mathrm{m}^{3} /$ year) \\
\hline 1 & Magothy & 45.09 \\
2 & Jameco & \\
3 & Lloyd & \\
4 & Upper glacial & \\
5 & Magothy & 4.55 \\
6 & & 0.59 \\
7 & & 5.26 \\
8 & Lloyd & 2.23 \\
9 & Lloyd & 3.10 \\
\hline
\end{tabular}

${ }^{a}$ Average annual, based on years 1990-2012 (Suozzi 2005) 
following.

\section{Spatial and temporal discretization}

A slice of the 3D modeling schematization and the assigned boundary conditions is illustrated in Fig. 6. The model domain is discretized in 35 rows, 29 columns, and 14 model layers, with horizontal cell sizes of $500 \mathrm{~m}$, and varying model layer thickness of 3-200 $\mathrm{m}$ in the vertical direction. The varying model layer thickness in the vertical direction is due to the varying thickness of geological layers and the occurrence of more intense hydrogeological processes near the ground surface. In temporal discretization, the simulation model is transient with a total simulation period of 18 years, from 2000 to 2018 . A total of 288 stress periods is used in the model, each representing 1 month of the simulation period.

\section{Boundary and initial conditions}

The boundary conditions of the model are defined either as the time-dependent specified head or as the no-flow boundaries (see Fig. 6). A specified head value of zero represents the mean sea level. The inland boundaries are assigned based on the groundwater-level contour lines, derived from head observation in the observation wells (USGS 2019a, b). Fresh groundwater sources are assigned to model cells on the land surface where recharge enters the groundwater system from the top (the salinity concentration is $0 \mathrm{~g} / \mathrm{L}$ TDS). A no-flow boundary is assumed at the bedrock and boundaries perpendicular to the shoreline and flow paths. A fixed salinity concentration of $35 \mathrm{~g} / \mathrm{L}$ TDS (Suozzi 2005; Misut and Voss 2007) is assigned to water that enters the model from the sea boundaries.

The 3D simulations start with saltwater conditions everywhere below the land surface and continue to run for a time that is long enough to reach a steady-state equilibrium. The steady-state equilibrium is approached asymptotically, and a cutoff is therefore assumed for the purposes of this analysis, after 10,000 years of simulation time. This final situation is considered as an initial condition in the automatic calibration procedure. Table 3 presents the characteristics of the simulation model including the simulation setup, spatial and temporal discretization, and boundary conditions.

\section{Hydrogeologic parameters}

The wide range of hydraulic conductivity values for each major geological layer (aquifer) (estimated from pump tests, empirical correlations with specific capacity values and grain size distributions) are reported in previous studies (McClymonds and Franke 1972; Prince and Schneider 1989; Lindner and Reilly 1983;
Fig. 6 A slice of the schematized 3D modeling with assigned boundary conditions and the range of (horizontal and vertical) hydraulic conductivity values as well as the specific yield for each geological layer. a Gulotta (1998), Buxton and Smolensky (1999), b Buxton and Smolensky (1999)

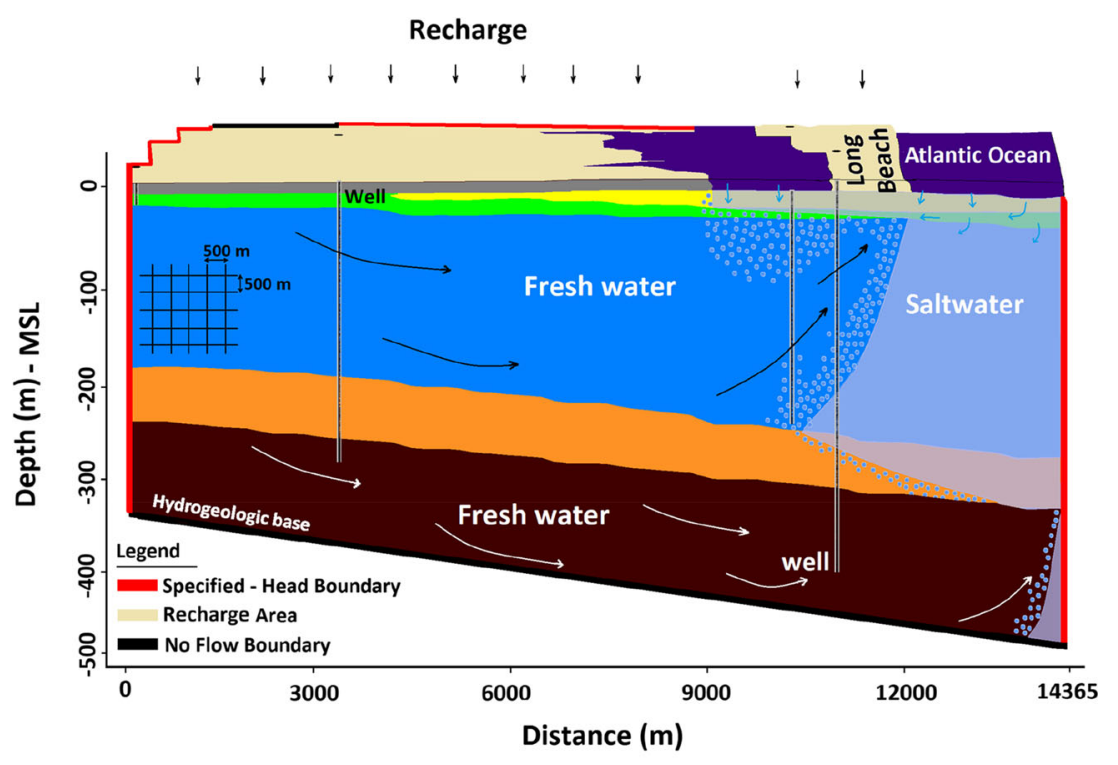

Legend 
Table 3 Summary of the simulation model characteristics

\begin{tabular}{|c|c|}
\hline Characteristic & Description \\
\hline \multicolumn{2}{|l|}{ Simulation setup } \\
\hline Dimension & Three-dimensional (3D) \\
\hline Porous media & Layered \\
\hline Simulation mode & Transient flow and transport \\
\hline \multicolumn{2}{|l|}{ Simulation model } \\
\hline Groundwater flow modeling & SEAWAT (Langevin et al. 2008) \\
\hline Realization & Monte Carlo \\
\hline Sampeling algotithm & Latin hypercube sampling \\
\hline \multicolumn{2}{|l|}{ Calibration } \\
\hline Auto-calibration code & PEST (Doherty 2005) \\
\hline Calibration basis & Head and salinity \\
\hline Dependent calibration variables & Recharge rate and hydraulic conductivity \\
\hline \multicolumn{2}{|l|}{ Spatial discretization } \\
\hline Grid type & Cell centered \\
\hline Number of rows & 35 \\
\hline Number of columns & 29 \\
\hline Number of model layers & 14 \\
\hline Number of realization & 150 \\
\hline Grid dimension (vertical direction) (m) & $3-200$ \\
\hline Grid dimension (horizontal direction) (m) & $500 \times 500$ \\
\hline \multicolumn{2}{|l|}{ Temporal discretization } \\
\hline Time to reach the steady-state condition (year) & 10,000 \\
\hline Time step for transient simulation (day) & 30 \\
\hline Stress period for transient simulation (month) & 228 \\
\hline \multicolumn{2}{|l|}{ Boundary conditions } \\
\hline Sea boundary & Seawater head \\
\hline Top surface boundary & Freshwater recharge \\
\hline Bottom surface boundary & No flow \\
\hline Inland boundary & Specified head \\
\hline
\end{tabular}

Getzen 1977; Franke and Getzen 1976). The hydraulic conductivity of each geological layer varies significantly from location to location. In addition, the horizontal hydraulic conductivity is often an order of magnitude or greater than the vertical hydraulic conductivity for that geological layer (Buxton and Smolensky 1999). Considering the same hydraulic conductivity value for each geological layer is a simple assumption and it has uncertainty; therefore, the uncertainty can significantly affect real-case outcomes compared to those initially expected. Figure 6 shows the range of hydraulic conductivity values for each geological layer, as well as the specific yield values, which take into account the geological heterogeneity of the unconfined aquifer system. The porosity is taken to be 0.3 (Getzen 1977; Misut and Voss 2007).

Also, the various ranges of the longitudinal dispersivity (include 20,50,125, and $150 \mathrm{~m}$ ) considering the scale dependency and the model cell size are assessed, and finally, the value of the longitudinal dispersivity is set to $125 \mathrm{~m}$. The ratio of the horizontal transverse dispersivity to the longitudinal dispersivity is 0.1 , while the ratio of the vertical transverse to the longitudinal dispersivity is 0.01 (Lin et al. 2009).

Table 4 Input parameters in numerical simulations

\begin{tabular}{lll}
\hline Parameter & Unit & Value \\
\hline Freshwater density & $\mathrm{g} / \mathrm{L}$ & 1,000 \\
Saltwater density & $\mathrm{g} / \mathrm{L}$ & 1,025 \\
Freshwater concentration & $\mathrm{g} / \mathrm{L}$ & 0 \\
Saltwater concentration & $\mathrm{g} / \mathrm{L}$ & 35 \\
Fluid dynamic viscosity & $\mathrm{g} / \mathrm{m} . \mathrm{s}$ & 1 \\
Molecular diffusion & $\mathrm{m}^{2} / \mathrm{s}$ & $1.48 \times 10^{-9}$ \\
Porosity & - & 0.30 \\
Specific storage & $\mathrm{L} / \mathrm{m}$ & 0.00001 \\
Specific yield & - & $0.15-0.30$ \\
Longitudinal dispersivity & $\mathrm{m}$ & 125 \\
Horizontal transverse dispersivity & $\mathrm{m}$ & 12.5 \\
Vertical transverse dispersivity & $\mathrm{m}$ & 1.25 \\
\hline
\end{tabular}


Fig. 7 Uncertain recharge rate $(\mathrm{mm} /$ year) for each zone in the numerical simulation

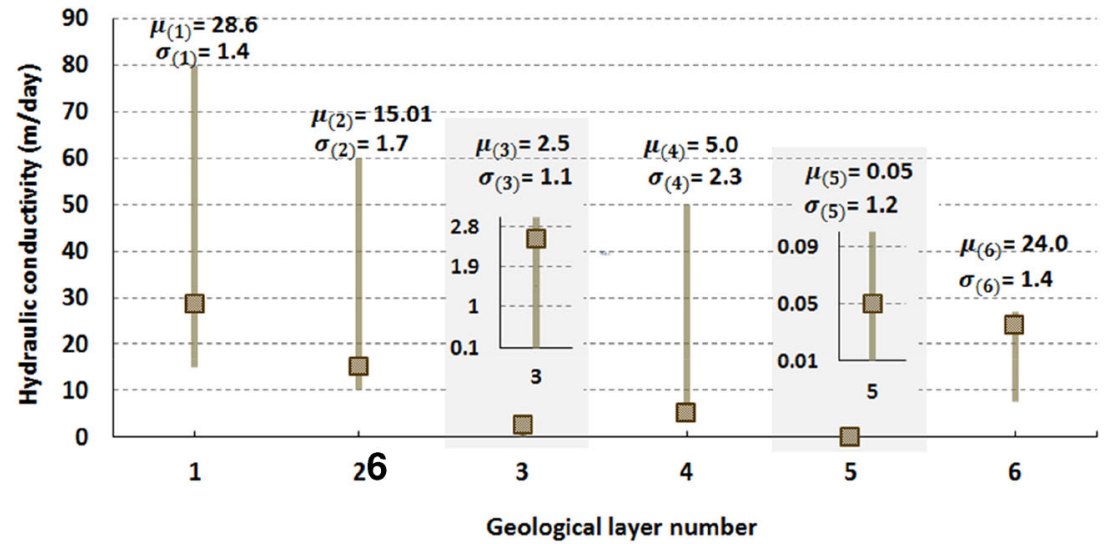

Table 4 summarizes the values of the input parameters for the numerical modeling.

\section{Considering uncertainties}

To account for the uncertainty in the simulation model, the input parameters that are considered to be uncertain include (1) the hydraulic conductivity of each geological layer, and (2) recharge rates in all water district areas. The uncertainty in these parameters is represented by normal probability distributions for recharge rates and log-normal probability distributions for hydraulic conductivity, with mean $(\mu)$ and standard deviation $(\sigma)$, as presented in Figs. 7 and 8. In these figures, lower and upper bound values as well as calibrated values from the simulation model are presented.

\section{Results and discussion}

In this section, model calibration and validation are explained with regard to assessing the performance of the groundwater model. Then, the salinity and groundwater level distributions under current conditions are described. Finally, the results of the risk analyses based on the defined indices are presented. In this study, the MATLAB platform is employed to execute all MCSs on a computer with a $3.50 \mathrm{GHz}$ Intel (R) Xeon 6144 CPU. The computational time of each simulation model takes 25-30 min, which is needed to repeat the computation around 150 times to cover the number of required runs.

\section{Model calibration and validation}

The calibration procedure is based on head measurements in 16 observation wells from 2000 to 2018. Chloride concentration was measured in 20 observation wells (SWI-monitoring wells) from 2000 to 2003. In these observation wells, head and salinity are measured at different depths. For head, five wells are in the Upper Glacial aquifer; there are also six and five wells in the Magothy and Lloyd aquifers, respectively. For the measured chloride concentrations, there are observationwell screens in four wells that sample in Jameco aquifer, and 12 and 4 wells that sample Magothy and Lloyd aquifers, respectively (see Fig. 2 for the locations of all the multi-level observation wells). In the calibration
Fig. 8 Uncertain hydraulic conductivity ( $\mathrm{m} /$ day) for each geological layer in the numerical simulation

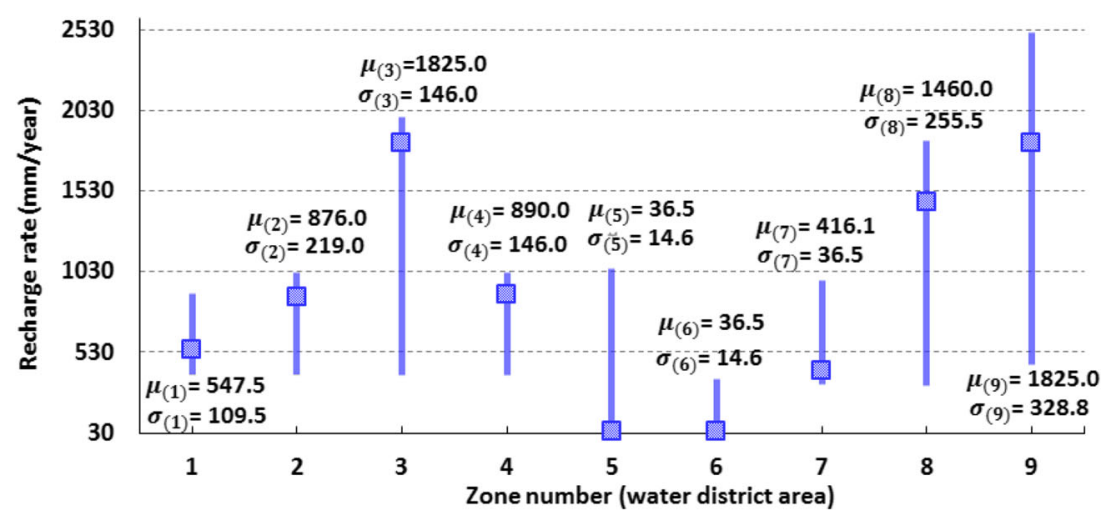


Fig. 9 Comparison of observed and simulated data for the steadystate models of $\mathbf{a}$ head and $\mathbf{b}$ concentration of total dissolved solids (TDS)

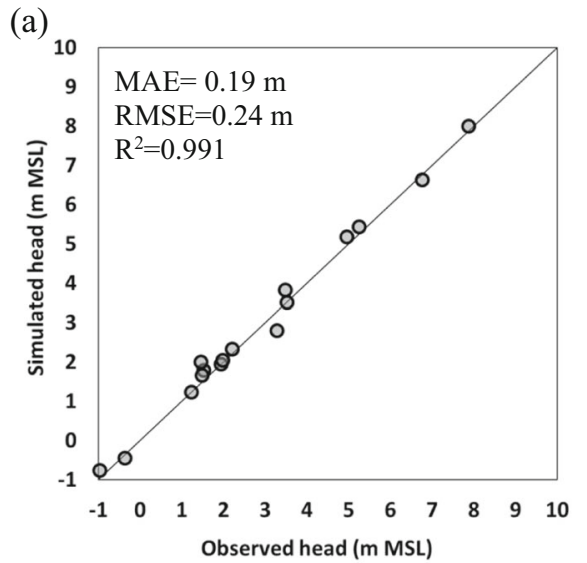

procedure, hydraulic conductivity and recharge rates are considered. Calibration of chloride concentration is conducted in the steady-state mode based on the measured data (2000-2013). Calibration of chloride in the transient simulation mode is done by adjusting the chloride concentration at pressure boundaries and the concentration of water extracted from the wells (similar to Ehtiat et al. 2018; Mostafaei-Avandari and Ketabchi 2020).

For the steady-state calibration (Fig. 9.), the mean absolute error (MAE) between the observed and simulated heads is $0.19 \mathrm{~m}$, and between the observed and simulated TDS concentrations is $0.30 \mathrm{~g} / \mathrm{L}$ TDS. After the steady-state calibration, these results are used for the transient simulation as initial estimations. Monthly groundwater-level data at 16 observation wells for years 2000-2013 and 2014-2018 are used as the observed data for transient calibration and validation, respectively.

The transient model performance based on the error indicators, is summarized in Table 5. As shown in this table, the (b)

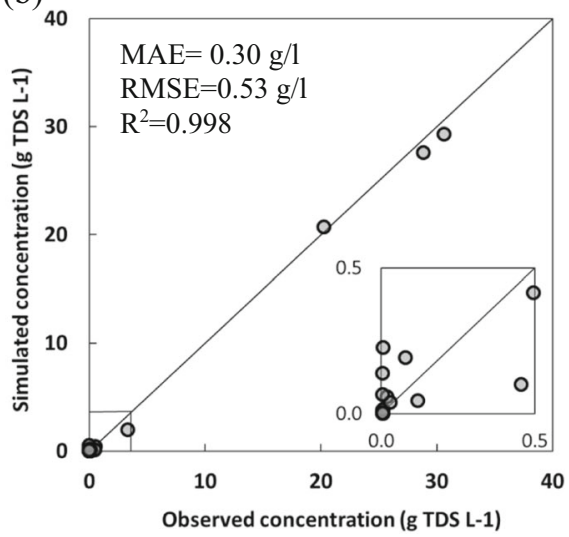

errors obtained from the steady-state and transient simulations indicate a good agreement between the observed and the simulated values.

\section{Status of groundwater system in the study area}

The groundwater system is simulated for 10,000 years to reach a steady-state equilibrium condition. For the duration of the steady-state equilibrium condition, it is assumed that the groundwater system is not affected by human intervention and climate-change factors. The results of the salinity and head simulations in the steadystate condition are used as the initial condition for a transient model, for which monitoring data are limited (see Michael et al. 2013; Mahmoodzadeh et al. 2014). In Fig. 10, the salinity and groundwater level distributions are shown for the year 2018.

As seen in Fig. 10a,b, SWI could be detected in the southern and southwestern part of Nassau County, in
Table 5 The values of errors for steady-state and transient modes

\begin{tabular}{|c|c|c|c|c|c|}
\hline \multicolumn{2}{|c|}{ Simulation mode } & \multirow{2}{*}{$\begin{array}{l}\text { Aquifer } \\
\text { Upper Glacial }\end{array}$} & \multirow{2}{*}{$\frac{\operatorname{MAE}(\mathrm{m})}{0.18}$} & \multirow{2}{*}{$\frac{\operatorname{RMSE}^{\mathrm{a}}(\mathrm{m})}{0.20}$} & \multirow{2}{*}{$\frac{R^{2 \mathrm{~b}}}{0.995}$} \\
\hline Steady-stat & & & & & \\
\hline & & Magothy & 0.16 & 0.18 & 0.996 \\
\hline & & Lloyd & 0.22 & 0.32 & 0.877 \\
\hline \multirow[t]{6}{*}{ Transient } & Calibration (2000-2013) & Upper Glacial & 0.18 & 0.27 & 0.973 \\
\hline & & Magothy & 0.14 & 0.23 & 0.988 \\
\hline & & Lloyd & 0.41 & 0.74 & 0.541 \\
\hline & Validation (2014-2018) & Upper Glacial & 0.05 & 0.15 & 0.965 \\
\hline & & Magothy & 0.09 & 0.21 & 0.975 \\
\hline & & Lloyd & 0.10 & 0.24 & 0.742 \\
\hline
\end{tabular}

${ }^{\mathrm{a}}$ Root mean square error (RMSE)

${ }^{\mathrm{b}}$ Squared correlation coefficient $\left(R^{2}\right)$ 
(a)

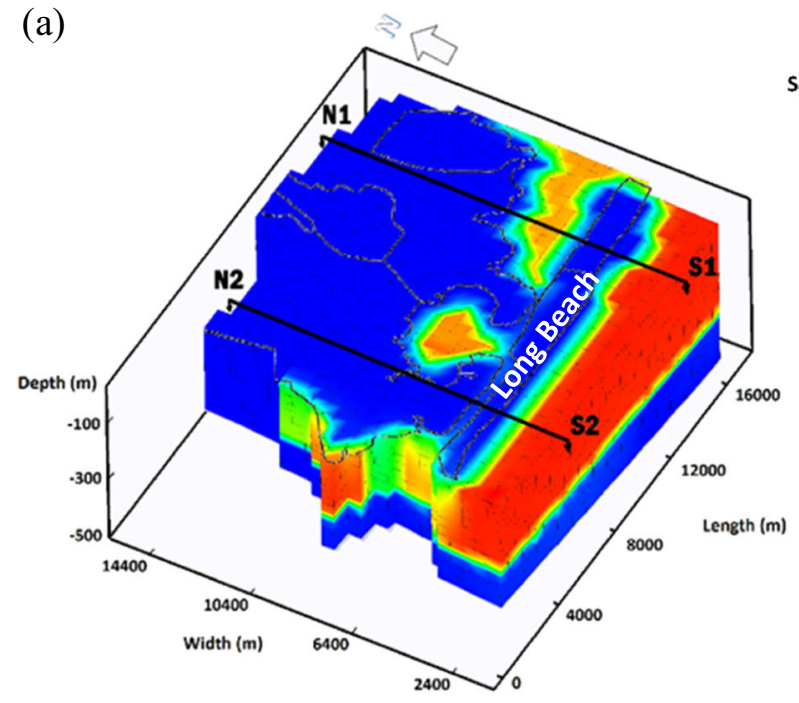

(b)

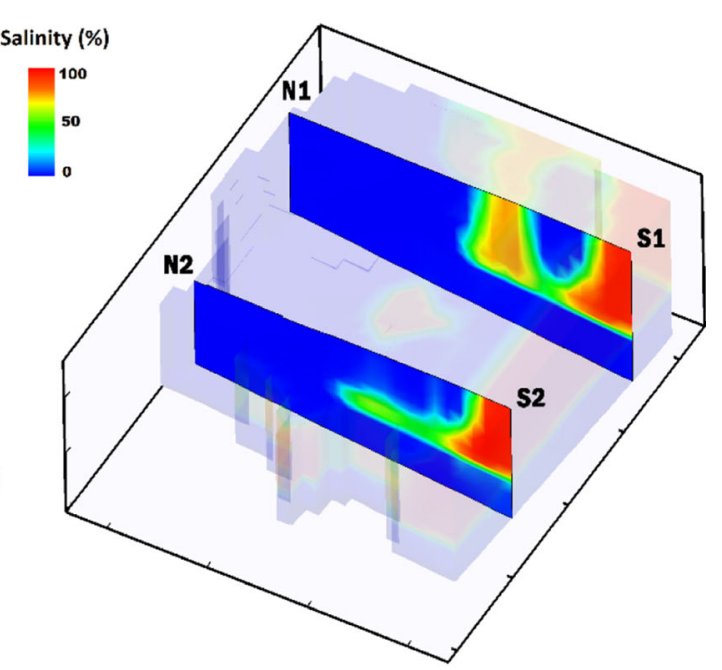

(c)

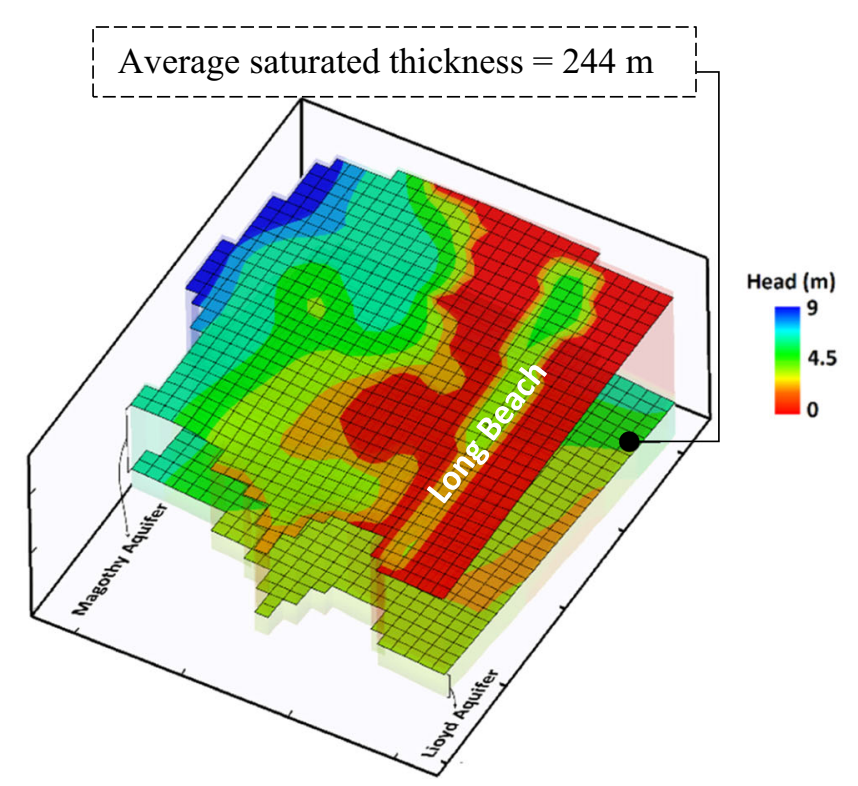

Fig. $103 \mathrm{D}$ modeling results of the study area: a salinity distribution in 3D, b salinity distribution in N1-S1 and N2-S2 cross-sections, and c groundwater level distributions (In Fig. 10b, the depths of the upper and lower slices are 100 and 500 m, respectively. Also in Fig. 10c, they are 100 and $400 \mathrm{~m}$, respectively)

\section{Risk analysis}

The results of the risk analyses under uncertainty for both the hydraulic conductivity and recharge rate parameters, based on the four defined indices in section 'Description of indices', are given in the following. Note that the risk values for the all indices are presented as normalized values.

\section{Decreasing groundwater level}

The risk values of decreasing groundwater level under $\alpha=5 \%$ are shown in Fig. 11. The results are presented for the Magothy aquifer, which is an unconfined aquifer the south. 
Fig. 11 Risk of decreasing groundwater level in the Magothy aquifer. A red area(risk $=\sim 1$ ) means the probability of groundwater level decrease is higher compared to other areas (the depth of the slice is $250 \mathrm{~m}$ )

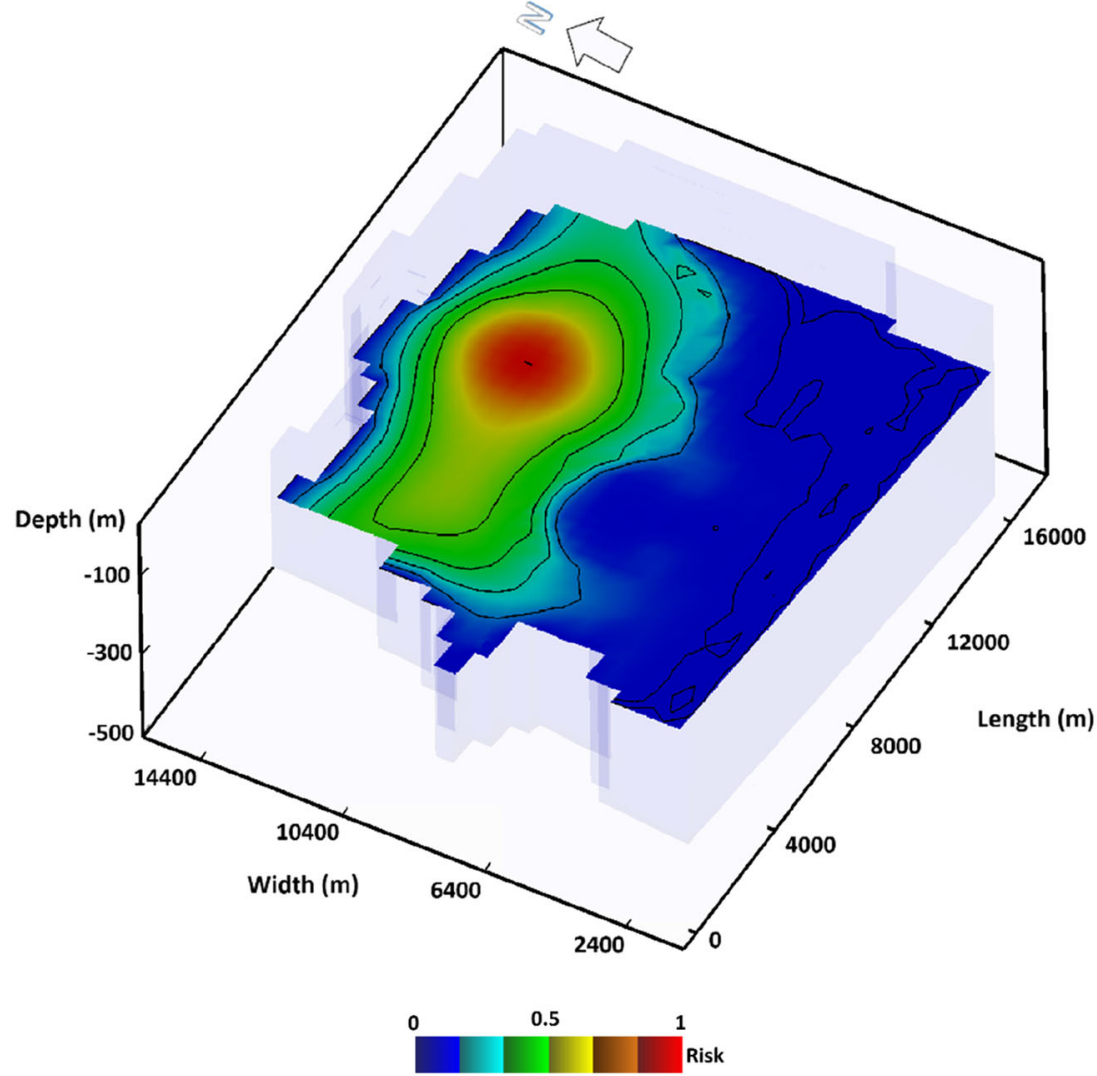

and has the highest groundwater level. Water district No. 5 and a portion of water district No. 1 have a higher risk of decreasing groundwater level than water districts located on Long Beach in the southern part of Nassau County.

In the water district Nos. 1 and 5, the groundwater consumption is about $80 \%$ from the Magothy aquifer. On Long Beach, groundwater is withdrawn only from the Lloyd aquifer. The results can be evaluated by water district managers in order to track trends in water usage throughout the study area and to monitor groundwaterlevel behavior. The average risk values under decreasing groundwater level for different confidence levels are shown in Table 6. The high confidence level (i.e. 100\%) means that, if repeated, the simulations give the same results. Also, the low value of confidence (i.e. $0 \%$ ) means

Table 6 The average risk value of depletion of groundwater level for different confidence levels, for the Magothy aquifer

Risk of depletion of groundwater level

\begin{tabular}{llll}
\hline $1 \pm \alpha=1.05$ & 1.2 & 1.4 & 1.6 \\
\hline 0.53 & 0.52 & 0.50 & 0.47 \\
\hline
\end{tabular}

there is no confidence that, if repeated, the simulations yield the same results.

The results obtained for various confidence levels are clearly consistent. A decrease in the average risk value is seen with an increase in confidence level. An increasing confidence level shows that the probability of exceedance (or probability of failure) is low and the risk of decreasing groundwater level has reduced. The average risk values are 0.53 and 0.47 for $\alpha=5$ and $60 \%$, respectively.

\section{Salinity concentration}

The risks of high salinity concentration due to the SWI threat for the Upper Glacial, Jameco, Magothy and Lloyd aquifers are shown in Fig. $12 \mathrm{a}-\mathrm{d}$. The results are presented for $95 \%$ confidence level and $5 \%$ of salinity concentration. As shown in this figure, several areas along the coastline are currently vulnerable to SWI. A notable area of high risk is north of Long Beach, where a large amount of groundwater withdrawal (55.11 million $\mathrm{m}^{3} /$ year) is occurring from the Magothy aquifer (Fig. 12c).

It is also observed that the risk of SWI has a nosignificance value in the Lloyd aquifer since the aquifer 
(a)

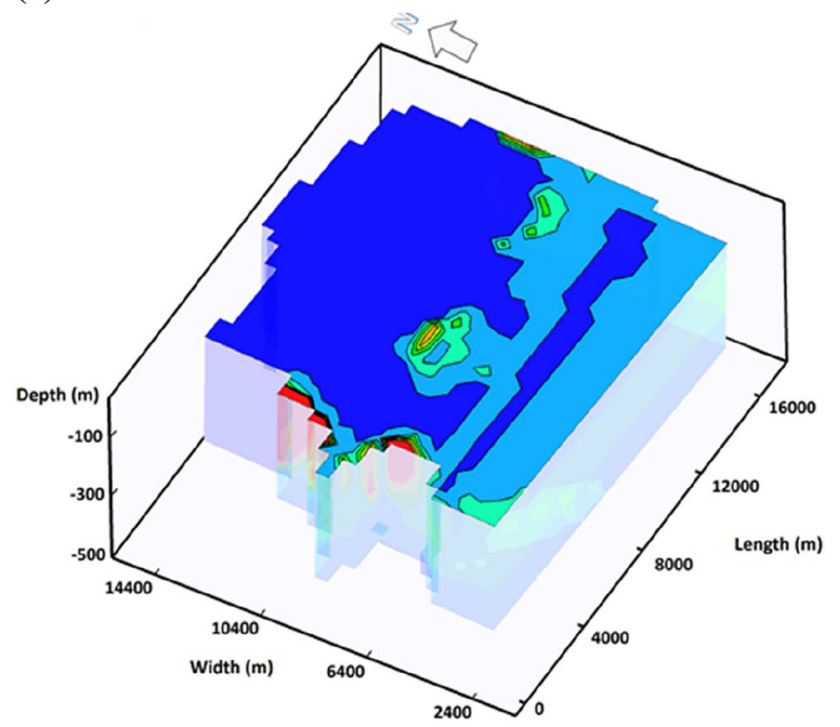

(c)

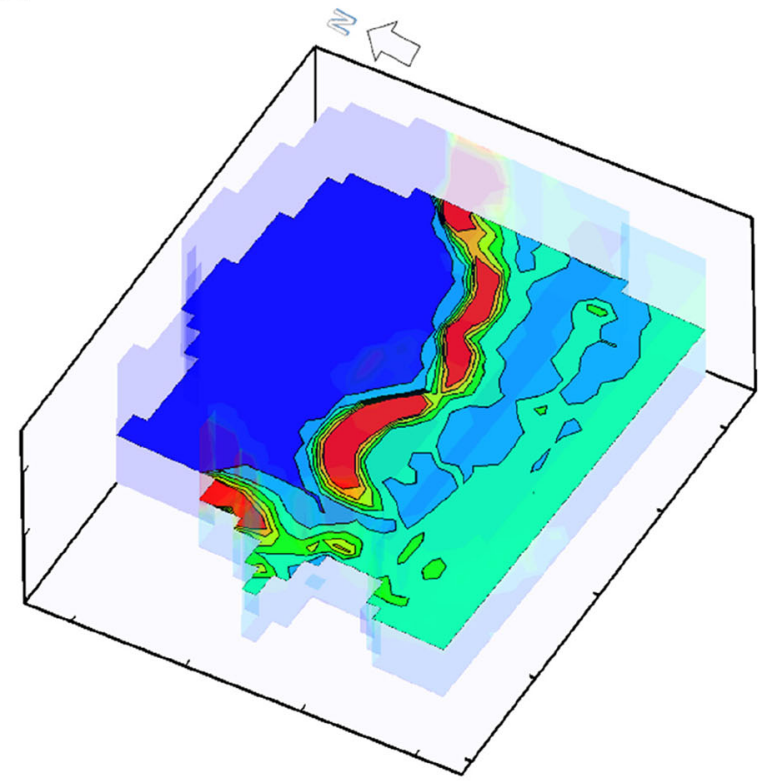

(b)

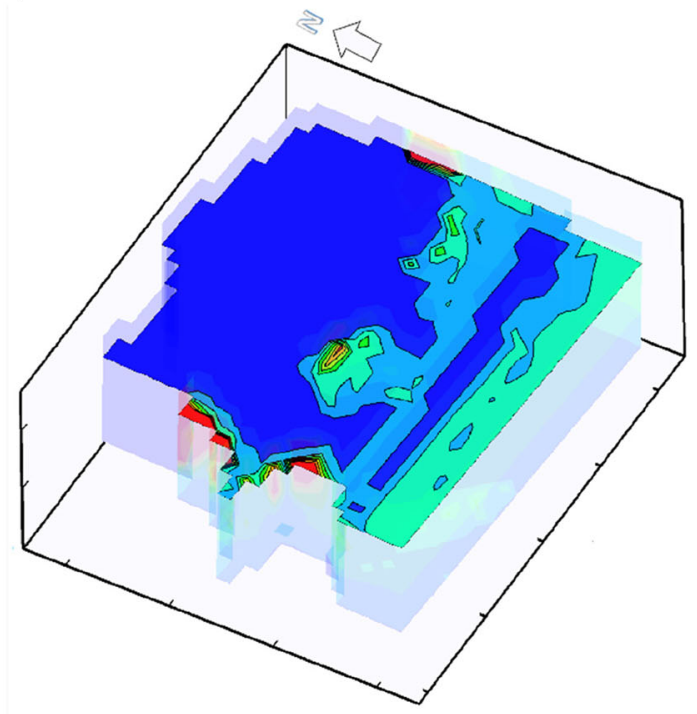

(d)

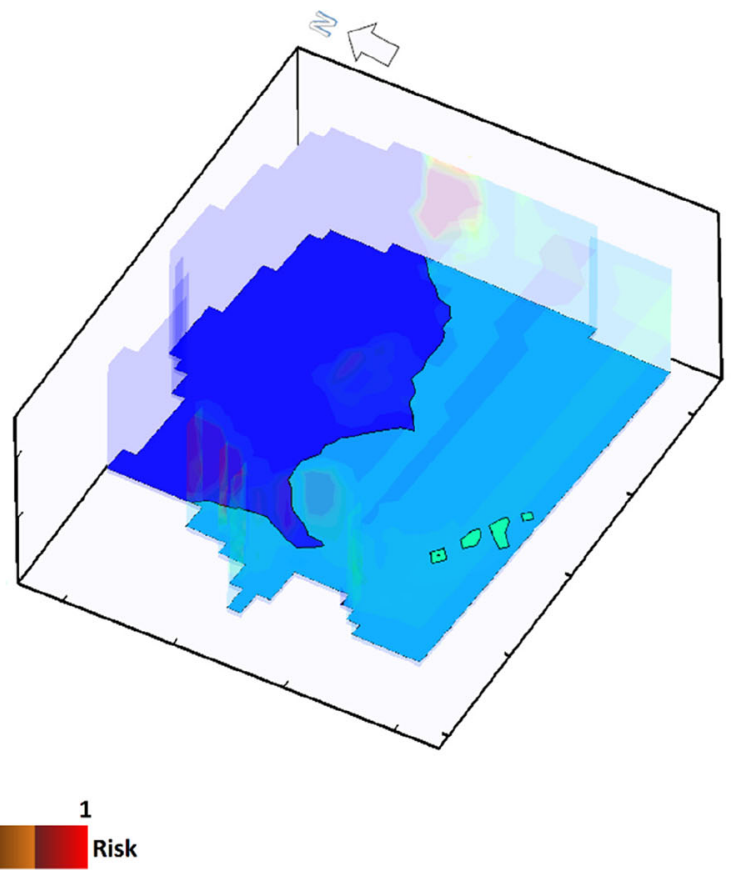

Fig. 12 The risk of SWI in the Nassau County aquifers: a Upper Glacial, b Jameco, c Magothy, and d Lloyd aquifers (In Fig. 12a-d, the depths of the slices are 100, 150, 250 and $450 \mathrm{~m}$, respectively)

is very deep and is protected by the low-permeability Raritan clay. Moreover, groundwater withdrawal from this aquifer is only $10 \%$ (5.9 million $\mathrm{m}^{3} /$ year) of the total extracted. The resulting risk value highlights the areas near municipal extraction wells and other major pumping wells, showing a large part of the area potentially exposed to SWI. The resulting risk maps can be used for risk management concerning SWI in the study area.

In Table 7, the detailed analysis is summarized for the average risk of SWI based on the salinity concentration at different thresholds, i.e. 0.2, 5, 50, and 95\% of salinity concentration in saltwater $\left(C_{\mathrm{sw}}\right)$, with a certain confidence level $(\alpha=5 \%)$. The higher value of risk 
Table 7 The average risk value of SWI based on the salinity concentration for different thresholds of salinity concentration in saltwater $\left(C_{\mathrm{sw}}\right)$; confidence level $=95 \%$

\begin{tabular}{lllll}
\hline Aquifer & \multicolumn{4}{l}{ Risk of SWI based on the salinity concentration } \\
\cline { 2 - 5 } & $C_{\mathrm{Tr}}=0.002 C_{\mathrm{sw}}$ & $0.05 C_{\mathrm{sw}}$ & $0.50 C_{\mathrm{sw}}$ & $0.95 C_{\mathrm{sw}}$ \\
\hline Upper Glacial & 0.13 & 0.80 & 0.01 & 0.02 \\
Jameco & 0.20 & 0.12 & 0.09 & 0.08 \\
Magothy & 0.39 & 0.31 & 0.23 & 0.18 \\
Lloyd & 0.005 & 0.003 & 0.0008 & 0.0005 \\
\hline
\end{tabular}

for the aquifer is seen in the threshold of potable water. The average risk values of SWI are estimated to be 0.39 and 0.20 for the Magothy and Jameco aquifers, respectively. In Table 7 , the values of 0.39 and 0.0005 show a higher and lower risk, respectively.

The average risk values of SWI $\left(0.50 C_{\mathrm{sw}}\right)$ for different confidence levels are summarized in Table 8. Increasing average risk values mean decreasing confidence levels. The results show that an increasing probability of failure equates to larger increases in salinity with respect to the zero-extraction scenario. The zeroextraction scenario shows that groundwater withdrawal does not happen throughout the simulation period. For instance, the obtained values of average risk are 0.23 and 0.33 for the confidence levels of 95 and $40 \%$, respectively, in the Magothy aquifer. These findings support the numerical results compared to the risk values of the first index that showed smaller risks while confidence levels increased.

\section{Filling ratio}

The results of the risk of SWI based on the filling ratio are summarized in Table 9 for the Upper Glacial, Jameco, Magothy and Lloyd aquifers. The results are presented for $\alpha=5 \%$ (a $95 \%$ confidence level), and at different thresholds of salinity concentration. The volumes of

Table 8 The average risk value of SWI for different confidence levels

\begin{tabular}{llllll}
\hline Aquifer & \multicolumn{4}{l}{ Risk of SWI based on the salinity concentration } \\
\cline { 2 - 6 } & $1 \pm \alpha=0.95$ & 0.9 & 0.8 & 0.6 & 0.4 \\
\hline Upper Glacial & 0.01 & 0.065 & 0.09 & 0.095 & 0.12 \\
Jameco & 0.09 & 0.11 & 0.15 & 0.16 & 0.19 \\
Magothy & 0.23 & 0.25 & 0.28 & 0.29 & 0.33 \\
Lloyd & 0.0008 & 0.0013 & 0.0018 & 0.0018 & 0.0022 \\
\hline
\end{tabular}

Table 9 The average risk value of SWI based on the filling ratio at different thresholds of salinity concentration in saltwater, for the $95 \%$ confidence level

\begin{tabular}{lllll}
\hline Aquifer & \multicolumn{4}{l}{ Risk of SWI based on the filling ratio } \\
\cline { 2 - 5 } & $C_{\mathrm{Tr}}=0.002 C_{\mathrm{sw}}$ & $0.05 C_{\mathrm{sw}}$ & $0.50 C_{\mathrm{sw}}$ & $0.95 C_{\mathrm{sw}}$ \\
\hline Upper Glacial & 0.60 & 0.005 & 0.004 & 0.001 \\
Jameco & 0.93 & 0.011 & 0.005 & 0.001 \\
Magothy & 0.88 & 0.022 & 0.018 & 0.004 \\
Lloyd & 0.25 & 0.006 & 0.0001 & 0.00007 \\
\hline
\end{tabular}

SWI based on the filling ratio, considering the $0.2,5$, 50 , and $95 \%$ of salinity concentration of saltwater, are estimated as 14,118.8, 7983.7, 6003.3, and 1838.8 million $\mathrm{m}^{3}$, respectively. As seen in Table 9, the average risk of SWI is estimated to be 0.93 and 0.88 for the Magothy and Jameco aquifers, respectively. This finding shows that the risk value of SWI seen in the threshold for potable water is higher for these aquifers in comparison with Glacial and Lloyd aquifers.

Also, the average risk values of SWI $\left(0.50 C_{\text {sw }}\right)$ for different confidence levels are summarized in Table 10. As for the previous indices on the risk of salinity concentration and decreasing groundwater level, increasing the probability of failure permits larger increases in salinities with respect to the zero-extraction scenario. For instance, the obtained values of average risk in the Magothy aquifer are 0.018 and 0.98 for the confidence levels of 95 and $40 \%$, respectively.

\section{Submarine groundwater discharge (SGD)}

Figure 13 shows groundwater flow paths and discharge towards the coastal ecosystem in the north of Long Beach and towards the Atlantic Ocean. In this area, the average SGD is estimated to be 81.4 million $\mathrm{m}^{3} /$ year;

Table 10 The average risk value of SWI based on the filling ratio for different confidence levels

\begin{tabular}{llllll}
\hline \multirow{2}{*}{ Aquifer } & \multicolumn{5}{l}{ Risk of SWI based on the filling ratio } \\
\cline { 2 - 6 } & $1 \pm \alpha=0.95$ & 0.9 & 0.8 & 0.6 & 0.4 \\
\hline Upper Glacial & 0.004 & 0.03 & 0.08 & 0.17 & 0.25 \\
Jameco & 0.005 & 0.07 & 0.18 & 0.36 & 0.54 \\
Magothy & 0.018 & 0.20 & 0.34 & 0.67 & 0.98 \\
Lloyd & 0.0001 & 0.001 & 0.004 & 0.004 & 0.008 \\
\hline
\end{tabular}


Fig. 13 Groundwater flow paths and the locations of flow discharging in the study area (the depths of the upper and lower slices are 250 and $450 \mathrm{~m}$, respectively)

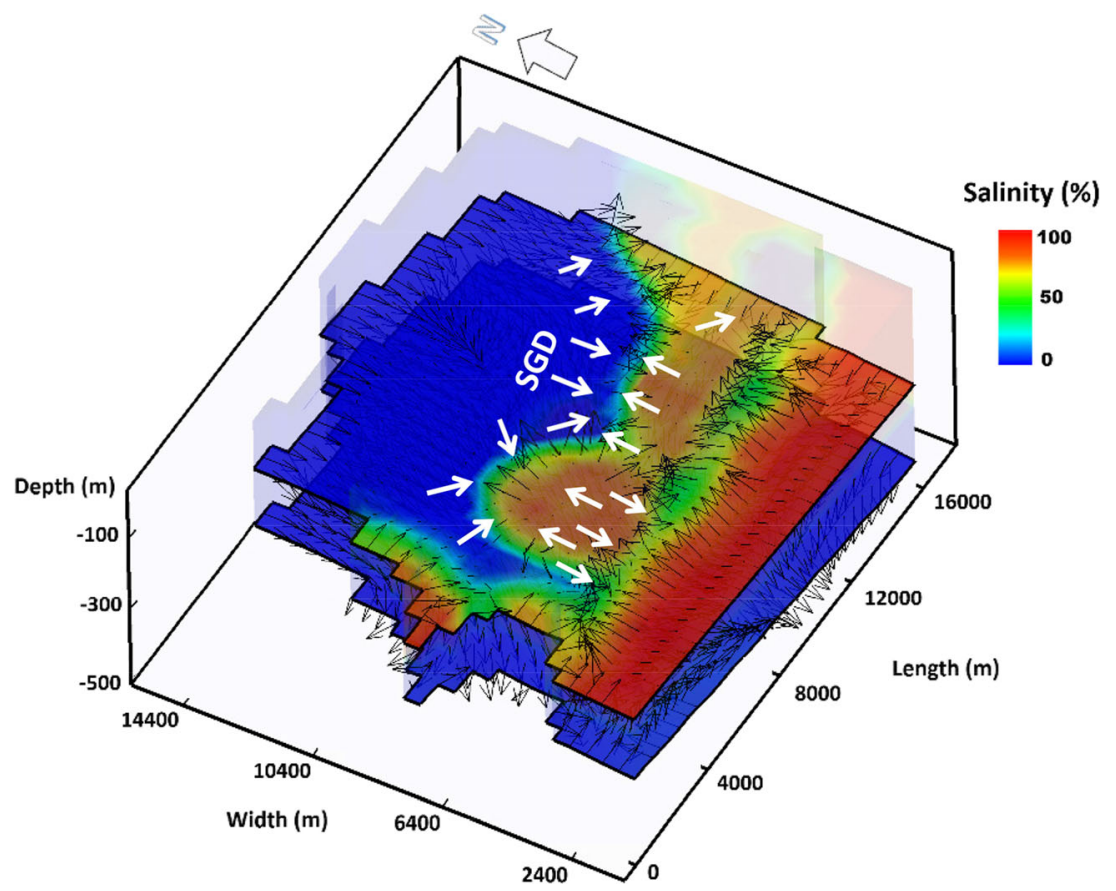

nitrate fluxes are associated with SGD and can damage the coastal ecosystems.

The average nitrate concentration, based on the water samples from wells, is classified as high $\left(2.3 \mathrm{mg} / \mathrm{L} \mathrm{NO}_{3}^{-}\right)$, medium $\left(0.86 \mathrm{mg} / \mathrm{L} \mathrm{NO}_{3}^{-}\right)$, and low $\left(0.60 \mathrm{mg} / \mathrm{L} \mathrm{NO}_{3}^{-}\right)$. Most wells in the study area have been rated as highly sensitive to contamination by nitrate (NYSDOH 2003). The average risk values of nitrate-contamination load discharging through SGD were estimated (see Table 11). The results show that the average risk value increases with a decrease in confidence level. For instance, the values of the obtained average risk are 0.05 and 0.91 for the confidence level of 95 and $40 \%$, respectively. Also, with a decrease in confidence level, the probability of failure permits larger increases in nitrate contamination load with respect to the zero-extraction scenario.

Table 11 The average risk to the aquifer of contamination load discharge through SGD

Risk of contamination load of discharge

\begin{tabular}{lllll}
\hline $1 \pm \alpha=0.95$ & 0.9 & 0.8 & 0.6 & 0.4 \\
\hline 0.05 & 0.06 & 0.09 & 0.42 & 0.91 \\
\hline
\end{tabular}

\section{Conclusions}

To achieve reliable solutions in the real world and in practical situations, it would be beneficial to consider uncertainty analysis in groundwater models. Moreover, the risk analysis and assessment of potential threats in the groundwater system are important issues. In this study, a 3D numerical model of variable-density groundwater flow and coupled salinity transport is conducted to assess the current status of groundwater levels, SWI status, and nitrate contamination load through SGD. The computer code SEAWAT is used to develop a numerical model and calibration was undertaken using PEST code as an automated parameter estimation procedure. A risk-based groundwater modeling framework is provided to classify the risk of potential threats in a real coastal aquifer system, located in Nassau County, New York. Monte Carlo simulation and Latin Hypercube Sampling are used to consider the uncertainty in both the hydraulic conductivity and the recharge rate. In the proposed framework, four indices are defined for the coastal aquifer in order to quantify the risk of (1) decreasing groundwater levels, (2) SWI based on the salinity concentration, (3) SWI (volume) based on the filling ratio and (4) nitrate contamination discharging through SGD.

The results show that SWI could be detected in the southern and southwestern parts of the Nassau County groundwater system, especially in the Magothy aquifer. The volume of SWI based on the filling ratio, considering 
a $50 \%$ saltwater interface (the salinity concentration greater than $50 \%$ of the maximum salinity concentration), is estimated to be $6,003.3$ million $\mathrm{m}^{3}$. This could be of concern because the Magothy aquifer is used as a significant water-supply source near the coastline. However, in the Lloyd aquifer it is not a major concern. In this study, the resulting indices are presented in spatial maps that classify areas of high risk to potential threats. The results show that water district No. 5 and a portion of water district No. 1 have a higher risk of decreasing groundwater level. Also, for SWI, a considerable area of high risk is seen in the northern part of Long Beach, where a high amount of groundwater withdrawal occurs from the Magothy aquifer. The SGDs associated with fluxes of nutrients are considerable and can damage the coastal ecosystems. The results of this study show that the proposed methodology is a valuable tool for water district managers to identify high-risk areas for short-term and long-term planning and it can be applied to other geographical settings.

Acknowledgements The first author of the paper was formerly a research professor at the Polytechnic Institute of NYU. Valuable support from the Utrecht University and Deltares during the second author's sabbatical program is greatly appreciated.

\section{Appendix: Notation list}

The following symbols are used in this paper:

SWI

SGD

LHS

3D

MCSs

$\rho_{0}$

$\mu$

$\mathrm{K}_{0}$

$h_{0}$

$S_{\mathrm{s}, 0}$

$\theta$

C

$q_{\mathrm{s}}^{\prime}$

$\rho_{\mathrm{b}}$

$\mathrm{D}$

$C^{k}$
$q$
$C_{\mathrm{s}}^{k}$
Saltwater intrusion

$t$

Submarine groundwater discharge

Latin hypercube sampling

Three-dimensional

Monte Carlo simulations

Fluid density at the reference concentration $\left[\mathrm{M} / \mathrm{L}^{3}\right]$

Dynamic viscosity $[\mathrm{M} / \mathrm{L} . \mathrm{T}]$

Hydraulic conductivity tensor at the

reference concentration $[\mathrm{L} / \mathrm{T}]$

Head at the reference concentration [L]

Specific storage at the reference

concentration $[1 / \mathrm{L}]$

Porosity [-]

Salt concentration $\left[\mathrm{M} / \mathrm{L}^{3}\right]$

Source or sink $[1 / \mathrm{T}]$ of fluid with density $\rho_{\mathrm{s}}$ Bulk density $\left[\mathrm{M} / \mathrm{L}^{3}\right]$

Distribution coefficient of species $k\left[\mathrm{~L}^{3} / \mathrm{M}\right]$

Hydrodynamic dispersion coefficient tensor

$\left[\mathrm{L}^{2} / \mathrm{T}\right]$

Concentration of species $k\left[\mathrm{M} / \mathrm{L}^{3}\right]$

Specific discharge $[\mathrm{L} / \mathrm{T}]$

Source or sink concentration $[\mathrm{M} / \mathrm{L}]$ of

species $k$
$I(x)$

$G(x)$

$P_{\mathrm{f}}$

$f_{x}(x)$

$N_{\mathrm{f}}$

$N$

$C_{m}$

$P\left(\mathrm{C}_{\mathrm{m}}\right)$

$H_{\mathrm{GWL}}$

$C_{\text {swi }}$

$\mathrm{FR}_{\text {swiv }}$

$P\left(H_{\mathrm{GWL}}^{x, y}\right)$

$H_{t}^{\text {allow }}$

$N_{\mathrm{MCS}}^{H_{t}^{x, y} \leq H_{t}^{\text {allow }}}$

$1 \pm \alpha$

$T$

K

$H_{\text {min }, t, k}^{x, y}$

Output of simulation model for each random variable $x$

Performance function

Probability of failure [-]

Probability density function of the random

variables $x$

Number of failures [-]

Total number of MCSs [-]

Characteristic of potential loss

at the specific event $m$

Probability of the potential loss at the specific event $m$

Decrease of groundwater level [L]

Salinity concentration $\left[\mathrm{M} / \mathrm{L}^{3}\right]$

Volsume of SWI based on the filling ratio

$\left[\mathrm{L}^{3}\right]$

Probability of exceedance of the

groundwater level [-] from a certain

threshold at each location in the aquifer $(x, y)$

Allowable decrease of groundwater level [L] in the $t^{\text {th }}$ stress period

Total number of MCSs resulting [-] in the decrease of groundwater level below $H_{t}^{\text {allow }}$ at each location in the aquifer $(\mathrm{x}, \mathrm{y})$

Confidence level for interval

Total number of assumed stress periods [-]

Stress period [T]

Total number of realizations

Minimum groundwater level [L] at each

location in the aquifer $(x, y)$ in the $t^{\text {th }}$ stress

period and $k^{\text {th }}$ realization

$L\left(H_{\mathrm{GWL}}^{x, y}\right)$

$\Delta H_{t, k}$

Severity of the failure event [-] at each

location in the aquifer $(x, y)$

Difference between the decrease of $H_{t}^{\text {allow }}$

and decrease groundwater level (in the $t^{\text {th }}$

stress period and $k^{\text {th }}$ realization)

$C_{\mathrm{swi}, t}^{x, y}$

$C_{\mathrm{sw}}$

$C_{\operatorname{Tr}}$

$C_{\text {swi,t }}^{\text {allow }}$

$P\left(C_{\mathrm{swi}}^{x, y, z}\right)$

$N_{\text {MCS }}^{C_{\text {swi, }}^{\text {xy,z } z} \geq C_{\text {swi, }, t}^{\text {allow }}}$

Salinity concentration $\left[\mathrm{M} / \mathrm{L}^{3}\right]$ at each

location and depth in the groundwater system $(x, y, z)$ and in the $t^{\text {th }}$ stress period

Salinity concentration of saltwater $\left[\mathrm{M} / \mathrm{L}^{3}\right]$

Threshold for the commonly used $0.2 \%, 5 \%$, $50 \%$, and $95 \%$ of $C_{\mathrm{sw}}\left[\mathrm{M} / \mathrm{L}^{3}\right]$

Allowable level of risk for salinity concentrations $\left[\mathrm{M} / \mathrm{L}^{3}\right]$ of SWI in the $t^{\text {th }}$ stress period

Probability of exceedance of salinity concentrations [-] at each location in the aquifer $(x, y, z)$ from a certain threshold

Number of MCSs resulting [-] in salinity concentrations of SWI above the threshold 


\begin{tabular}{|c|c|}
\hline$C_{\text {max,swi,t }}^{x, y, z}$ & $\begin{array}{l}\text { Maximum salinity concentration }\left[\mathrm{M} / \mathrm{L}^{3}\right] \text { in } \\
\text { the } t^{\text {th }} \text { stress period and at each location in the } \\
\text { aquifer }(x, y, z)\end{array}$ \\
\hline$L\left(C_{\mathrm{swi}}^{x, y, z}\right)$ & $\begin{array}{l}\text { Magnitude of the failure event }[-] \text { at each } \\
\text { location in the aquifer }(x, y, z)\end{array}$ \\
\hline$\Delta C_{t, k}$ & $\begin{array}{l}\text { Difference between the salinity } \\
\text { concentrations and the } C_{\mathrm{swi}, t}^{\text {allow }} \text { (in the } k^{\text {th }} \\
\text { realization and in the } t^{\text {th }} \text { stress period) }\end{array}$ \\
\hline $\mathrm{FR}_{\text {swiv }}^{i}$ & $\begin{array}{l}\text { Ratio of the occupied volume by saltwater in } \\
i^{\text {th }} \text { model layer }[-]\end{array}$ \\
\hline$V_{j, t}^{i}$ & $\begin{array}{l}\left.\text { Volume of SWI [ } \mathrm{L}^{3}\right] \text { in the } t^{\text {th }} \text { model layer, in } \\
\text { the } j^{\text {th }} \text { model cell, and in the } t^{\text {th }} \text { stress period }\end{array}$ \\
\hline$V_{j}^{i}$ & Volume of the model cell $\left[\mathrm{L}^{3}\right]$ \\
\hline$C_{j, t}^{i}$ & Salinity concentration $\left[\mathrm{M} / \mathrm{L}^{3}\right]$ \\
\hline$C_{\mathrm{Tr}}$ & $\begin{array}{l}\text { Certain threshold for the salinity } \\
\text { concentration }\left[\mathrm{M} / \mathrm{L}^{3}\right]\end{array}$ \\
\hline $\mathrm{FR}_{\text {swiv }}^{\text {allow }}$ & $\begin{array}{l}\text { Allowable level of risk for filling ratio of } \\
\text { SWI }\end{array}$ \\
\hline$P\left(\mathrm{FR}_{\mathrm{swiv}}^{i}\right)$ & $\begin{array}{l}\text { Probability of exceedance of the ratio of the } \\
\text { occupied volume by saltwater }[-] \text { in the } i^{\text {th }}\end{array}$ \\
\hline & model layer from a $\mathrm{FR}_{\text {swiv }}^{\text {allow }}$ \\
\hline 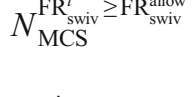 & $\begin{array}{l}\text { Number of MCSs resulting [-] in the filling } \\
\text { ratio of SWI above } \mathrm{FR}_{\text {swiv }}^{\text {allow }}\end{array}$ \\
\hline $\mathrm{FR}_{\text {max }, \text { swiv }}^{i, z}$ & $\begin{array}{l}\text { Maximum filling ratio }[-] \text { under the zero- } \\
\text { extraction scenario, in the } i^{\text {th }} \text { model layer }\end{array}$ \\
\hline$L\left(\mathrm{FR}_{\mathrm{swiv}}^{\mathrm{i}}\right)$ & $\begin{array}{l}\text { Severity of the failure event }[-] \text { in the } i^{\text {th }} \\
\text { model layer }\end{array}$ \\
\hline$\Delta \mathrm{FR}_{k}$ & $\begin{array}{l}\text { Difference between the ratio of the occupied } \\
\text { volume by saltwater (in the } i^{\text {th }} \text { model layer } \\
\text { and in the } k^{\text {th }} \text { realization) and the } \mathrm{FR}_{\text {swiv }}^{\text {allow }}\end{array}$ \\
\hline $\mathrm{CL}_{\mathrm{SGD}}$ & $\begin{array}{l}\text { Average concentration of contamination load } \\
\text { discharge through } \mathrm{SGD}[\mathrm{M} / \mathrm{T}]\end{array}$ \\
\hline $\bar{C}$ & Average concentration $\left[\mathrm{M} / \mathrm{L}^{3}\right]$ \\
\hline $\mathrm{SGD}_{t}$ & $\begin{array}{l}\text { Discharging flow out of the aquifers to the } \\
\text { sea in each stress period }\left[\mathrm{L}^{3} / \mathrm{T}\right]\end{array}$ \\
\hline $\mathrm{CL}_{\mathrm{SGD}}^{\text {allow }}$ & $\begin{array}{l}\text { Allowable level of risk for the contamination } \\
\text { load in the } i^{\text {th }} \text { model layer }\end{array}$ \\
\hline$P\left(\mathrm{CL}_{\mathrm{SGD}}\right)$ & $\begin{array}{l}\text { Probability of exceedance of the average } \\
\text { contamination load that discharges through } \\
\text { SGD to sea from } \mathrm{CL}_{\mathrm{SGD}}^{\text {allow }}\end{array}$ \\
\hline $\mathrm{CL}_{\max , \mathrm{SGD}, z}^{\text {allow }}$ & $\begin{array}{l}\text { Maximum contamination load }[\mathrm{M} / \mathrm{T}] \text { among } \\
\text { all realizations under the zero-extraction } \\
\text { scenario }\end{array}$ \\
\hline$\Delta \mathrm{CL}_{k}$ & $\begin{array}{l}\text { Difference between the average } \\
\text { contamination of the aquifer in the } k^{\text {th }} \\
\text { realization and the } \mathrm{CL}_{\mathrm{SGD}}^{\text {allow }}\end{array}$ \\
\hline TDS & Total dissolved solids \\
\hline$\mu$ & Mean \\
\hline$\sigma$ & Standard deviation \\
\hline MA & Mean absolute error \\
\hline & Root mean square error \\
\hline & Squared correlation coefficie \\
\hline
\end{tabular}

Open Access This article is licensed under a Creative Commons Attribution 4.0 International License, which permits use, sharing, adaptation, distribution and reproduction in any medium or format, as long as you give appropriate credit to the original author(s) and the source, provide a link to the Creative Commons licence, and indicate if changes were made. The images or other third party material in this article are included in the article's Creative Commons licence, unless indicated otherwise in a credit line to the material. If material is not included in the article's Creative Commons licence and your intended use is not permitted by statutory regulation or exceeds the permitted use, you will need to obtain permission directly from the copyright holder. To view a copy of this licence, visit http://creativecommons.org/licenses/by/4.0/.

\section{References}

Baalousha HM (2003) Risk assessment and uncertainty analysis in groundwater modelling. PhD Thesis, der RWTH Aachen, Bibliothek, Aachen, Germany

Burnett WC, Bokuniewicz H, Huettel M, Moore WS, Taniguchi M (2003) Groundwater and pore water inputs to the coastal zone. Biogeochemistry 66:3-33

Buxton HT, Smolensky DA (1999) Simulation of the effects of development of the ground-water flow system of Long Island, New York. US Geol Surv Water Resour Invest 98-4069

Cohen P, Franke OL, Foxworthy BL (1968) An atlas of Long Island's water resources: New York state. Water Resour Bull 62-117

Colombani N, Osti A, Volta G, Mastrocicco M (2016) Impact of climate change on salinization of coastal water resources. Water Resour Manag 30(7):2483-2496

Dimov IT (2008) Monte Carlo methods for applied scientists. World Scientific, Singapore

Doherty J (2005) PEST: model independent parameter estimation: user manual, 5th edn. Watermark, Brisbane, Australia

Ehtiat M, Mousavi JS, Srinivasan R (2018) Groundwater modeling under variable operating conditions using SWAT, MODFLOW and MT3DMS: a catchment scale approach to water resources management. Water Resour Manag 32(5):1631-1649

Eriksson M, Ebert K, Jarsjö J (2018) Well salinization risk and effects of Baltic Sea level rise on the groundwater-dependent island of Öland, Sweden. Water 10(2):141

Franke OL, Getzen RT (1976) Evaluation of hydrologic properties of the Long Island ground-water reservoir using cross-sectional electricanalog models. US Geological Survey 75-679

Getzen RT (1977) Analog-model analysis of regional three-dimensional flow in the ground-water reservoir of Long Island New York. US Geol Survey Prof Pap 982:49

Gulotta TS (1998) Nassau County 1998 groundwater study. Report, Nassau County Department of Public Works, Mineola, NY

Holding S, Allen DM (2015) From days to decades: numerical modelling of freshwater lens response to climate change stressors on small lowlying islands. Hydrol Earth Syst Sci 19:933-949

Holding S, Allen DM (2016) Risk to water security for small islands: an assessment framework and application. Reg Environ Chang 16(3): $827-839$

Huizer S, Radermacher M, De Vries S, Oude Essink GHP, Bierkens MFP (2018) Impact of coastal forcing and groundwater recharge on the growth of a fresh groundwater lens in a mega-scale beach nourishment. Hydrol Earth Syst Sci 22(2):1065-1080

Karamouz M, Ahmadi A, Akhbari M (2020) Groundwater hydrology: engineering, planning, and management. CRC, Boca Raton, FL 
Karamouz M, Mohammadpour P, Mahmoodzadeh D (2017) Assessment of sustainability in water supply-demand considering uncertainties. Water Resour Manag 31(12):3761-3778

Ketabchi H, Ataie-Ashtiani B (2015a) Evolutionary algorithms for the optimal management of coastal groundwater: a comparative study toward future challenges. J Hydrol 520:193-213

Ketabchi H, Ataie-Ashtiani B (2015b) Review: Coastal groundwater optimization-advances, challenges, and practical solutions. Hydrogeol J 23(6):1129-1154

Ketabchi H, Mahmoodzadeh D, Ataie-Ashtiani B, Simmons CT (2016a) Sea-level rise impacts on seawater intrusion in coastal aquifers: review and integration. J Hydrol 535:235-255

Ketabchi H, Mahmoodzadeh D, Ataie-Ashtiani B (2016b) Groundwater travel time computation for two-layer islands, Hydrogeol J 24(4): $1045-1055$

Klassen J, Allen DM (2017) Assessing the risk of saltwater intrusion in coastal aquifers. J Hydrol 551:730-745

Lal A, Datta B (2019) Optimal groundwater-use strategy for saltwater intrusion management in a Pacific Island country. J Water Resour Plan Manag 145(9):04019032

Langevin CD, Thorne Jr DT, Dausman AM, Sukop MC, Guo W (2008) SEAWAT version 4: a computer program for simulation of multispecies solute and heat transport. Geological Survey Techniques and Methods 6-A22, US Geological Survey, Reston, VA, 39 pp

Lassila P, Karvo J, Virtamo J (1999) Efficient importance sampling for Monte Carlo simulation of loss systems. In: Proceedings of the ITC16. Edinburgh, June 1999, pp 787-796

Lin J, Snodsmith JB, Zheng C, Wu J (2009) A modeling study of seawater intrusion in Alabama Gulf Coast, USA. Environ Geol 57(1):119 130

Lindner JB, Reilly TE, (1983) Analysis of three tests of the unconfined aquifer in southern Nassau County, Long Island, New York. US Geol Surv Water Resour Invest Rep 82-4021, 46 pp

Lusczynski N J, Swarzenski W V (1966) Salt-water encroachment in southern Nassau and southeastern Queens counties, Long Island, New York. US Geol Surv Water Supply Pap 1613-F

Mahmoodzadeh D, Karamouz M (2017) Influence of coastal flooding on seawater intrusion in coastal aquifers. In: Dunn CN, Van Weele B (eds) World Environmental and Water Resources Congress, Sacramento, CA, May 2017, pp 66-79.10.1061/ 9780784480618.007

Mahmoodzadeh D, Karamouz M (2019) Seawater intrusion in heterogeneous coastal aquifers under flooding events. J Hydrol 568:11181130

Mahmoodzadeh D, Ketabchi H, Ataie-Ashtiani B, Simmons CT (2014) Conceptualization of a fresh groundwater lens influenced by climate change: a modeling study of an arid-region island in the Persian Gulf, Iran. J Hydrol 519:399-413

Massone HE, Barilari A (2019) Groundwater pollution: a discussion about vulnerability, hazard and risk assessment. Hydrogeol J 28: 463-466

McClymonds NE, Franke OL (1972) Water-transmitting properties of aquifers on Long Island, New York. US Geol Surv Prof Pap $637-$ E, $24 \mathrm{pp}$

Michael HA, Russoniello CJ, Byron LA (2013) Global assessment of vulnerabilityto sea-level rise in topography-limited and rechargelimited coastal groundwater systems. Water Resour Res 49(4): 2228-2240

Minderhoud PSJ, Erkens G, Van Hung P, Vuong BT, Erban LE, Kooi H, Stouthamer E (2017) Impacts of 25 years of groundwater extraction on subsidence in the Mekong Delta, Vietnam. Environ Res Lett 12(6):064006

Misut PE, Voss CI (2004) Simulation of seawater intrusion resulting from proposed expanded pumpage in New York City, USA. In Developments in Water Science, Elsevier, 55:1595-1606
Misut PE, Voss CI (2007) Freshwater-saltwater transition zone movement during aquifer storage and recovery cycles in Brooklyn and Queens, New York City, USA. J Hydrol 337:87-103

Moore WS (2010) The effect of submarine groundwater discharge on the ocean. Annu Rev Mar Sci 2:59-88

Moreno LJA, Lemus DDSZ, Rosero JL, Morales DMA, Castaño LMS, Cuervo DP (2020) Evaluation of aquifer contamination risk in urban expansion areas as a tool for the integrated management of groundwater resources: case - coffee growing region, Colombia. Groundw Sustain Develop 10:100298

Mostafaei-Avandari M, Ketabchi H (2020) Coastal groundwater management by an uncertainty-based parallel decision model. J Water Resour Plan Manag 146(6):04020036

Motallebian M, Ahmadi H, Raoof A, Cartwright N (2019) An alternative approach to control saltwater intrusion in coastal aquifers using a freshwater surface recharge canal. J Contaminant Hydrol 222:56-64

Narayan KA, Schleeberger C, Bristow KL (2007) Modelling seawater intrusion in the Burdekin Delta Irrigation Area, North Queensland, Australia. Agric Water Manag 89(3):217-228

New York State Department of Health (NYSDOH) (2003) Long Island Source Water Assessment Program. https://www.health.ny.gov. Accessed June 2020

Nobre RCM, Rotunno Filho OC, Mansur WJ, Nobre MMM, Cosenza CAN (2007) Groundwater vulnerability and risk mapping using GIS, modeling and a fuzzy logic tool. J Contam Hydrol 94(3-4): 277-292

Oude Essink GHP, Van Baaren ES, De Louw PGB (2010) Effects of climate change on coastal groundwater systems: a modeling study in the Netherlands. Water Resour Res 46:W00F04

Perlmutter NM, Geraghty JJ (1963) Geology and ground-water conditions in southern Nassau and southeastern Queens counties, Long Island, New York. US Geol Surv Water Suppl Pap 1613-A

Peterson DS (1987) Ground-water-recharge rates in Nassau and Suffolk counties, New York. US Geol Surv Water Resour Invest Rep 87

Post VE, Essink GO, Szymkiewicz A, Bakker M, Houben G, Custodio E, Voss C (2018) Celebrating 50 years of SWIMs (Salt Water Intrusion Meetings). Hydrogeol J 26(6):1767-1770

Press WH, Teukolsky SA, Vetterling WT, Flannery BP (1992) Numerical recipe in Fortran: the art of scientific computing, 2nd edn. Cambridge University Press, New York

Prince KR, Schneider BJ (1989) Estimation of hydraulic characteristics of the Upper Glacial and Magothy Aquifers at East Meadow, New York, by use of aquifer tests. US Geol Surv Water Resour Invest Rep 87-4211

Rajabi MM, Ataie-Ashtiani B (2014) Sampling efficiency in Monte Carlo based uncertainty propagation strategies: application in seawater intrusion simulations. Adv Water Resour 67:46-64

Rajabi MM, Ketabchi H (2017) Uncertainty-based simulation-optimization using Gaussian process emulation: application to coastal groundwater management. J Hydrol 555:518-534

Rasmussen P, Sonnenborg TO, Goncear G, Hinsby K (2013) Assessing impacts of climate change, sea level rise, and drainage canals on saltwater intrusion to coastal aquifer. Hydrol Earth Syst Sci 17(1): 421-443

Simpson WM, Allen DM, Journeay MM (2014) Assessing risk to groundwater quality using an integrated risk framework. Environ Earth Sci J 71(11):4939-4956

Slomp CP, Van Cappellen P (2004) Nutrient inputs to the coastal ocean through submarine groundwater discharge: controls and potential impact. J Hydrol 295:64-86

Small C, Nicholls RJ (2003) A global analysis of human settlement in coastal zones. J Coastal Res 19(3):584-599

Smolensky DA, Buxton HT, Shernoff PK (1989) Hydrologic framework of Long Island, NewYork. US Geol Surv Hydrol Invest Atlas HA709, 3 sheets, scale 1:250,000 
Stumm F, Lange AD, Candela JL (2002) Hydrogeology and extent of saltwater intrusion on Manhasset Neck, Nassau County, New York. US Geol Surv Water Resour Invest Rep 00-4193

Suozzi, TR (2005) Groundwater Monitoring Program 2000-2003 report. Nassau County Dept. of Public Works, Mineola, NY

Thorn P (2011) Groundwater salinity in Greve, Denmark: determining the source from historical data. Hydrogeol J 19(2):445-461

USGS (2019a) Groundwater data for New York. US Geological Survey database available online. https://waterdata.usgs.gov/ny/nwis/gw. Accessed March 2019

USGS (2019b) Groundwater watch. US Geological Survey database available online. https://groundwaterwatch.usgs.gov/. Accessed March 2019

USGS (2019c) Science base. US Geological Survey Science Base available online. https://www.sciencebase.gov/catalog/. Accessed March 2019

Van Camp M, Radfar M, Walraevens K (2010) Assessment of groundwater storage depletion by overexploitation using simple indicators in an irrigated closed aquifer basin in Iran. Agric Water Manag 97(11):1876-1886
Werner AD, Bakker M, Post VE, Vandenbohede A, Lu C, Ataie-Ashtiani B, Simmons CT, Barry DA (2013) Seawater intrusion processes, investigation and management: recent advances and future challenges. Adv Water Resour 51:3-26

Xiao H, Wang D, Medeiros SC, Bilskie MV, Hagen SC, Hall CR (2019) Exploration of the effects of storm surge on the extent of saltwater intrusion into the surficial aquifer in coastal east-central Florida (USA). Sci Total Environ 648:1002-1017

Yang J, Graf T, Herold M, Ptak T (2013) Modelling the effects of tides and storm surges on coastal aquifers using a coupled surface-subsurface approach. J Contam Hydrol 149:61-75

Yao Y, Andrews C, Zheng Y, He X, Babovic V, Zheng C (2019) Development of fresh groundwater lens in coastal reclaimed islands. J Hydrol 573:365-375

Zeng X, Wu J, Wang D, Zhu X (2016) Assessing the pollution risk of a groundwater source field at western Laizhou Bay under seawater intrusion. Environ Res 148:586-594

Zhou Y, Sawyer AH, David CH, Famiglietti JS (2019) Fresh submarine groundwater discharge to the near-global coast. Geophys Res Lett 46(11):5855-5863 